\title{
PENATAAN ULANG KEWENANGAN PENYIDIKAN DAN PENUNTUTAN DALAM PENEGAKAN HUKUM PELANGGARAN HAM BERAT
}

\author{
Febriansyah Ramadhan \\ Fakultas Hukum Universitas Brawijaya \\ email:mrfebri18@gmail.com \\ Xavier Nugraha \\ Fakultas Hukum Univeristas Airlangga \\ email: nugrahaxavier72@gmail.com \\ Patricia Inge Felany \\ Fakultas Hukum Universitas Airlangga \\ email: ingefell123@gmail.com
}

disampaikan 3/11/19 - di-review 13/2/20 - diterima 4/6/2020

DOI: $10.25123 /$ vej.3514

\begin{abstract}
This article discusses the problems encountered in the preliminary court proceeding of gross human right violation cases in Indonesia. Identified are two state institutions, i.e. the National Human Right Commission and the Attorney General, who possess the authority to initiate investigation and subsequent successful prosecution of gross human right violation cases. Good cooperation and relation between these two agencies is therefore a must. This article looks into the problems encountered by these two institutions in doing the preliminary process and discusses possible redistribution of these two state agency authorities. To do this a doctrinal approach will be used.
\end{abstract}

Keywords:

National Human Right Commission, Attorney General, gross human right violation, investigation-

prosecution

\begin{abstract}
Abstrak
Tulisan ini menelaah proses awal pemeriksaan dan pengadilan tindak pidana pelanggaran hak asasi manusia berat di Indonesia. Ditenggarai bahwa untuk itu ada dua lembaga Negara yang punya peran sentral, yaitu Jaksa Agung dan KomNas HAM. Kedua lembaga ini yang bertanggungjawab untuk menginisiasi kegiatan penyelidikan, penyidikan dan selanjutnya penuntutan pelanggaran hak asasi manusia berat dan artinya penuntasan kasus-kasus ini. Hubungan yang baik dan kerjasama antara kedua lembaga Negara ini adalah keniscayaan. Satu persoalan yang ditelaah di sini ialah, mengingat acap terjadinya kemacetan proses di atas, adalah bagaimana menata ulang kewenangan kedua lembaga tersebut dalam rangka menjamin penuntasan perkara pelanggaran hak asasi manusia berat di masa depan. Untuk itu digunakan pendekatan doctrinal.
\end{abstract}

Kata Kunci:

Komnas-HAM; pelanggaran HAM berat; penuntutan; penyidikan 


\section{Pendahuluan}

Pelanggaran Hak Asasi Manusia Berat (Pelanggaran HAM berat) masa lalu, masih belum terselesaikan, alhasil Pemerintah masih menangung beban kewajiban pada setiap korban/keluarga pelanggaran HAM berat. Ragam instrumen hukum sudah dibentuk oleh Pembentuk Undang-Undang, namun masih sulit untuk diterapkan. Ragam instrumen hukum mengenai penyelesaian pelanggaran HAM Berat, sebagai berikut:

1. Undang-Undang Nomor 26 tahun 2000 tentang Pengadilan Hak Asasi Manusia (UU Pengadilan HAM);

2. Undang-Undang Nomor 27 tahun 2004 tentang Komisi Kebenaran dan Rekonsiliasi (UU KKR).

Keberadaan instrumen hukum tersebut, belum mampu menuntaskan pelanggaran HAM berat dan memulihkan hak korban. Belum adanya pengadilan HAM yang diselenggarakan, alhasil pihak-pihak yang berkepentingan dengan pengusutuan pelanggaran HAM berat melakukan judicial review UU Pengadilan HAM ke Mahkamah Konstitusi. Hingga detik ini, terdapat lima Putusan Mahkamah Konstitusi (Putusan MK):

Tabel 1: Daftar Putusan MK tentang Pengujian Undang-Undang Pengadilan HAM dan UU KKR

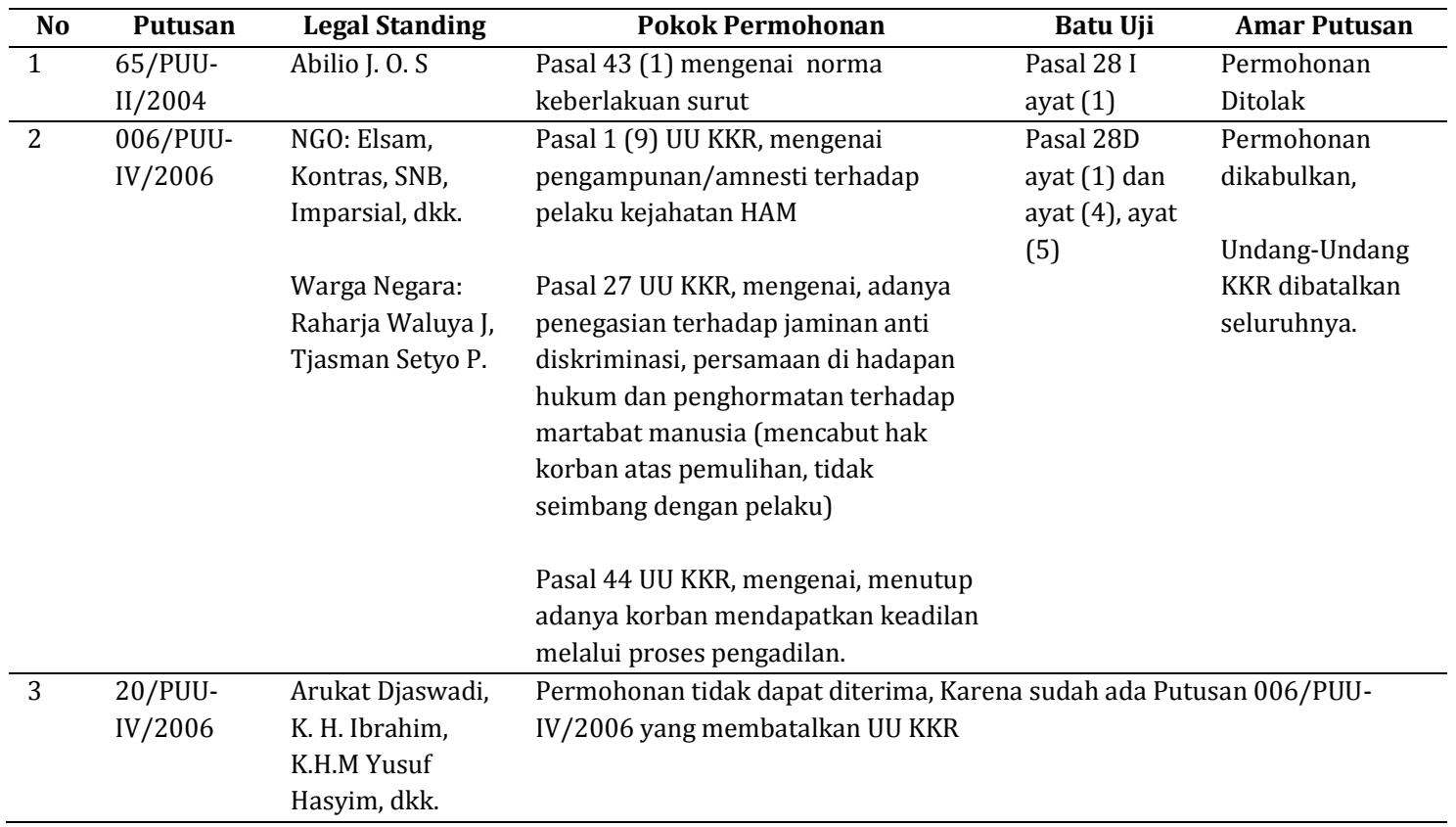




\begin{tabular}{|c|c|c|c|c|c|}
\hline 4 & $\begin{array}{l}\text { 18/PUU- } \\
\text { V/2007 }\end{array}$ & Eurico Guterres & $\begin{array}{l}\text { Pasal } 43 \text { ayat (2) dan Penjelasan Pasal } \\
43 \text { ayat (2) mengenai peran DPR } \\
\text { dalam pembentukan pengadilan HAM } \\
\text { ad-hoc }\end{array}$ & $\begin{array}{l}\text { Pasal } 27 \text { ayat } \\
\text { (1), Pasal } \\
\text { 28D ayat (1), } \\
\text { Pasal 28G } \\
\text { ayat (1) ju. } \\
\text { Pasal 24A } \\
\text { ayat (5), } \\
\text { Pasal 28 I } \\
\text { ayat (2) }\end{array}$ & $\begin{array}{l}\begin{array}{l}\text { Permohonan } \\
\text { dikabulkan } \\
\text { sebagian }\end{array} \\
\text { Menyatakan } \\
\text { Penjelasan Pasal } \\
43 \text { ayat (2) UU } \\
\text { Pengadilan HAM } \\
\text { bertentangan } \\
\text { dengan UUD } \\
\text { 1945, batal, dan } \\
\text { tidak memiliki } \\
\text { kekuatan hukum } \\
\text { mengikat } \\
\end{array}$ \\
\hline 5 & $\begin{array}{l}\text { 75/PUU- } \\
\text { XIII/2015 }\end{array}$ & $\begin{array}{l}\text { Paian Siahaan } \\
\text { dan Yati Ruyati }\end{array}$ & $\begin{array}{l}\text { Pasal } 20 \text { ayat (3) mengenai } \\
\text { pengembalian berkas (bolak-balik } \\
\text { perkara) dari Jaksa Agung kepada } \\
\text { Komnas-HAM, yang tidak memiliki } \\
\text { kepastian hukum. }\end{array}$ & $\begin{array}{l}\text { Pasal 28D } \\
\text { ayat (1), 28H } \\
\text { ayat (2), } \\
\text { Pasal 28I } \\
\text { ayat (2) }\end{array}$ & $\begin{array}{l}\text { Ditolak } \\
\text { Seluruhnya. }\end{array}$ \\
\hline
\end{tabular}

Sumber: Diolah penulis dari berbagai sumber perundang-undangan.

Dari putusan yang ada, putusan 006/PUU-IV/2006 adalah salah satu putusan yang fenomenal, dimana MK memberikan putusan ultra petita dalam petitum pemohon, dengan membatalkan keseluruhan UU KKR. ${ }^{1}$ MK berpendapat tidak adanya nuansa keadilan dalam UU KKR sebagai instrumen hukum penyelesaian pelanggaran HAM berat, UU KKR dinilai tidak memiliki orientasi keadilan kepada korban, dan tidak memiliki kepastian terhadap pelaku karena terdapat alternatif pilihan penyelesaian pelanggaran HAM berat, yakni KKR dan Pengadilan HAM. ${ }^{2}$ Kerugian yang diajukan oleh para pemohon dalam putusan ini adalah kerugian yang bersifat potensial (belum terjadi), namun MK mengabulkan, karena argumentasi yang diajukan rasional dalam penalaran hukum yang wajar dan sesuai dengan asas-asas hukum HAM.

Berbeda hal-nya dengan tahun 2015, melalui putusan 75/PUU-XIII/2015, pengujian terhadap UU Pengadilan HAM, didasarkan pada kerugian yang bersifat langsung dan spesifik, dalam arti para pemohon 'sudah' merasakan secara langsung kerugian dari keberlakukan norma dalam UU Pengadilan HAM. Bentuk kerugian tersebut, dialami karena adanya masalah antar kelembagaan yang

1 “Menyatakan Undang-Undang Republik Indonesia Nomor 27 Tahun 2004 Tentang Komisi Kebenaran Dan Rekonsiliasi bertentangan dengan Undang-Undang Dasar Republik Indonesia Tahun 1945". Lihat dalam hlm., 131, Putusan 006/PUU-IV/2006.

2 Lihat hlm., 128 Putusan 006/PUU-IV/2006. 
'diduga' tidak satu visi dalam penyelesaian pelanggaran HAM berat. Pemohon menguji pasal 20 UU Pengadilan HAM, yang berbunyi:

1. Dalam hal Komisi Nasional Hak Asasi Manusia berpendapat bahwa terdapat bukti permulaan yang cukup telah terjadi peristiwa pelanggaran hak asasi manusia yang berat, maka kesimpulan hasil penyelidikan disampaikan kepada penyidik.

2. Paling lambat 7 (tujuh) hari kerja setelah kesimpulan hasil penyelidikan disampaikan, Komisi Nasional Hak Asasi Manusia menyerahkan seluruh hasil penyelidikan kepada penyidik.

3. Dalam hal penyidik berpendapat bahwa hasil penyelidikan sebagaimana dimaksud dalam ayat (2) masih kurang lengkap, penyidik segera mengembalikan hasil penyelidikan tersebut kepada penyelidik disertai petunjuk untuk dilengkapi dan dalam waktu 30 (tiga puluh) hari sejak tanggal diterimanya hasil penyelidikan, penyelidik wajib melengkapi kekurangan tersebut.

Membaca keberadaan pasal tersebut, tidak bisa terlepas dari pasal lainya, yakni Pasal 18 UU Pengadilan HAM yang mengatur kewenangan Komnas HAM melakukan penyelidikan, Pasal 21 UU Pengadilan HAM yang mengatur kewenangan Jaksa Agung melakukan penyelidikan. Rangkaian kewenangan tersebut, adalah konsekuensi dari Pasal 10 UU Pengadilan HAM, yang mengatur hukum acara atas perkara pelanggaran hak asasi manusia yang berat dilakukan berdasarkan ketentuan hukum acara pidana, dimana hukum acara pidana merujuk kepada Undang-Undang Nomor 18 tahun 1881 tentang Kitab UndangUndang Hukum Acara Pidana sebagai lex generali. Artinya, dalam melaksanakan hukum acara pelanggaran HAM Berat, terdapat 3 (tiga) tiga kekuasaan yang saling berseberangan, yakni lembaga independen (Komnas-HAM) yang melaksanakan penyelidikan, kekuasaan eksekutif (Jaksa Agung) yang melaksanakan penyidikan, dan penuntutan, dan kekuasaan yudikatif (Pengadilan HAM - Mahkamah Agung), yang melaksanakan Pengadilan.

Adanya lintas kekuasaan dalam hukum acara pelanggaran HAM berat, menjadikan kesatuan visi penegakan hukum menjadi hal yang perlu 
dikhawatirkan. Kekhawatiran tersebut, yang menjadikan Paian Siahaan dan Yati Ruyati menguji Pasal 20 UU Pengadilan HAM di MK. Pemohon mendapatkan ketidakpastian hukum, karena Jaksa Agung sering membolak-balik berkas pelanggaran HAM berat ke Komnas-HAM. Pemohon meminta MK untuk menambahkan Pasal 20 ayat (3) UU Pengadilan HAM menjadi, "Dalam hal penyidik berpendapat bahwa hasil penyelidikan sebagaimana dimaksud dalam ayat (2) masih kurang lengkap, penyidik segera mengembalikan hasil penyelidikan tersebut kepada penyidik disertai petunjuk yang jelas sebagaimana Pasal 8 dan Pasal 9 untuk 3 dilengkapi dan dalam waktu 30 (tiga puluh) hari sejak tanggal diterimanya hasil penyelidikan, penyelidik wajib melengkapi kekurangan tersebut". Adapun Pasal 8, adalah penjabaran lebih rinci dari jenis kejahatan genosida, dan Pasal 9 adalah penjabaran lebih rinci dari kejahatan kemanusiaan.

Melalui Putusan Nomor 75/PUU-XIII/2015, Permohonan tersebut ditolak oleh MK. Terhadap putusan tersebut, penulis memberikan catatan penting yang harus dicermati: Pertama, dalam pertimbanganya, Mahkamah menyatakan bahwa fenomena bolak-balik berkas itu adalah masalah penerapan hukum, bukan masalah pertentangan norma/konstitusionalitas. ${ }^{3}$ Kedua, tetapi di sisi lain dalam pertimbangan berikutnya, Mahkamah tidak menafikkan dan mengakui bahwa pemohon sudah mengalami ketidakpastian hukum dalam penanganan pelanggaran HAM Berat. Selain itu, MK juga memberikan rekomendasi kepada pembentuk undang-undang di masa mendatang untuk melengkapi ketentuan dalam Pasal 20 UU Pelanggaran HAM Berat, guna memberi jalan keluar terhadap tiga persoalan penting, yaitu: 4

1. Penyelesaian atau jalan keluar dalam hal terjadi perbedaan pendapat yang berlarut-larut antara Penyelidik (Komnas HAM) dan Penyidik (Jaksa Agung) mengenai dugaan adanya pelanggaran hak asasi manusia yang berat, khususnya kelengkapan hasil penyelidikan;

2 Penyelesaian atau jalan keluar apabila tenggang waktu 30 (tiga puluh) hari sebagaimana dimaksud dalam Pasal 20 ayat (3) UU 26/2000 terlampaui dan

3 Pertimbangan Hakim Putusan Nomor 75/PUU-XIII/2015, hlm., 82.

$4 \quad$ Pertimbangan Hakim Putusan Nomor 75/PUU-XIII/2015, hlm., 85. 
Penyelidik (Komnas HAM) tidak mampu melengkapi kekurangan hasil penyelidikannya;

3. Langkah-langkah hukum yang dapat ditempuh oleh warga negara yang merasa dirugikan oleh pengaturan pada angka (1) dan angka (2) di atas.

Ketiga, jika dipahami secara utuh pertimbangan MK, rupanya pendekatan yang dilakukan oleh Mahkamah sangat tekstual, membatasi diri, dengan menggunakan penafsiran originalism. MK menegaskan bahwa persoalan perbedaan pendapat antara Jaksa Agung dan Komnas HAM, serta ketidaklengkapan norma Pasal 20 UU Pengadilan HAM mengenai konsekuensi jika Komnas-HAM dalam waktu 30 hari tidak mampu melengkapi pemberkasan yang dikembalikan dari Jaksa Agung, bukanlah kewenangan MK, dan merupakan domain dari legislative review. Dalam batas penalaran yang wajar, MK tidak mungkin memberikan rekomendasi terhadap DPR dan Presiden, jika memang tidak ada permasalahan norma. Tentu ada permasalahan norma, yang kemudian berpengaruh kepada penerapan hukum.

Keempat, harus disadari bahwa empat kewenangan MK dan 1 kewajiban, ${ }^{5}$ merupakan perpaduan antara dimensi hukum dan politik. Tetapi dalam pertimbangan tersebut, argumentasi yang menyangkut politik penegakan hukum dan politik kelembagaan, sama sekali tidak terbahas. Padahal pelanggaran HAM berat selalu berkaitan dengan rezim kekuasaan, dan penegakannya tentu harus dilakukan secara independent-mandiri. Eddy O.S Hiariej mengatakan: 6

"tidak bisa dipungkiri, bahwa penindakan pelanggaran HAM berat dengan menggunakan instrumen hukum pidana tidaklah mudah, karena lebih

5 Berdasarkan Pasal 24C ayat (1) UUD 1945 yang ditegaskan kembali dalam Pasal 10 ayat (1) huruf a sampai dengan d Undang-Undang Nomor 24 tahun 2003 tentang Mahkamah Konstitusi, kewenangan Mahkamah Konstitusi adalah: 1. Menguji undang-undang terhadap UUD 1945, 2. Memutus sengketa kewenangan lembaga negara yang kewenangannya diberikan oleh UUD 1945. 3. Memutus pembubaran partai politik; dan 4. Memutus perselisihan tentang hasil pemilihan umum. Selain itu, berdasarkan Pasal 7 ayat (1) sampai dengan (5) dan Pasal 24C ayat (2) UUD 1945 yang ditegaskan lagi oleh Pasal 10 ayat (2) UU 24/2003, kewajiban Mahkamah Konstitusi adalah memberikan keputusan atas pendapat DPR bahwa Presiden dan/atau Wakil Presiden telah melakukan pelanggaran hukum, atau perbuatan tercela, atau tidak memenuhi syarat sebagai Presiden dan/atau Wakil Presiden sebagaimana dimaksud dalam UUD 1945.

6 Eddy OS Hiariej, Pengadilan atas Beberapa Kejahatan Serius Terhadap HAM, Penerbit Erlangga, Jakarta, 2010, hlm., 02. 
bernuansa politik daripada masalah hukum. Disatu sisi, dalam konteks hukum pidana nasional, situasi politik suatu negara sangat mempengaruhi penindakan terhadap pelakunya, karena biasanya berkaitan erat dengan otoritarian suatu rezim. Sedangkan di sisi lain, dalam konteks hukum pidana internasional, terdapat tarik menarik antara kedaulatan suatu negara yang dihadapkan dengan tuntutan masyarakat internasional dalam penegakan hak asasi manusia. Kompleksitas masalah ini diperumit dengan adanya sikap politik yang selalu mendua dari negara-negara barat terhadap pelanggaran hak asasi manusia yang berat yang dilakukan secara sistematis dibelahan bumi lainnya".

Keempat otokritik terhadap putusan tersebut, menandakan bahwa masalah penegakan pelanggaran HAM berat masih harus dilakukan secara multidimensi. Tulisan ini, adalah bagian dari upaya untuk memecahkan silangsengkarut penegakan pelanggaran HAM berat, dengan pendekatan kelembagaaninstitusional. Perlu ada evaluasi struktur kelembagaan penanganan pelanggaran HAM berat, dengan peningkatan independensi Komnas-HAM, terlebih penanganan tersebut menggunakan instrumen hukum pidana, ${ }^{7}$ yang selalu berkelindan dengan sektor politik-kekuasaan.

Secara penerapan hukum, ternyata setiap penyelidikan terkait pelanggaran HAM berat yang dilakukan oleh Komnas HAM selalu dikembalikan oleh jaksa agung. Misal, kasus Wasior dan Wamena yang terjadi pada tahun 2002-20038, kasus pelanggaran berat HAM di Aceh seperti kasus Jambu Kepok, kasus Simpang KKA dan dan kasus Rumah Geudong yang diserahkan pada 2017-2018. ${ }^{9}$ Hal ini merupakan suatu problematika sejatinya, karena jika melihat pengaturan secara normatif, seharusnya dalam 90 hari penyidik wajib diselesaikan dan dikatakan lengkap oleh penyidik. Dalam hal waktu tersebut, jika tidak cukup, memang dapat diperpanjang 90 hari, kemudian jika tidak cukup lagi dapat ditambah 60 hari. Dalam jangka waktu tersebut, jika penyidikan tidak diperoleh bukti yang cukup,

7 Lihat dalam Pasal 10 UU Pelanggaran HAM Berat: Dalam hal tidak ditentukan lain dalam Undang-undang ini, hukum acara atas perkara pelanggaran hak asasi manusia yang berat dilakukan berdasarkan ketentuan hukum acara pidana.

8 Komnas HAM, Jurnal HAM: Komisi Hak Asasi Manusia, Jurnal HAM, Volume 13, No. 8, 2016, hlm., 12. Hal ini juga dapat dilihat dalam Putusan Putusan Nomor 75/PUU-XIII/2015.

9 Ayomi Amindoni, "Kejaksaan Agung kembalikan berkas kasus pelanggaran HAM berat, bagaimana komitmen Presiden Jokowi?", https://www.bbc.com/indonesia/indonesia46822119, diakses 6 Juni 2019. 
maka wajib dikeluarkan surat penghentian penyidikan oleh Jaksa Agung. Namun ternyata, Jaksa Agung selalu mengembalikan berkas penyelidikan yang diberikan oleh Komnas HAM dengan alasan berkas tersebut tidak memenuhi persyaratan formil dan materiil. Padahal tenggang waktu penyidikan tersebut jauh melampauhi waktu yang ditentukan, mengingat hingga penelitian ini dibuat yaitu 2019, sudah lebih dari waktu yang ditentukan untuk kasus Wasior pada tahun 2001, kasus Wamena yang terjadi pada tahun 2003, dan untuk kasus berat HAM di Aceh seperti kasus Jambu Kepok, kasus Simpang KKA dan dan kasus Rumah Geudong yang diserahkan pada 2017-2018.

Hal ini menimbulkan problematika dari segi hukum, terkait alasan Jaksa agung yang selalu melimpahkan kembali berkas penyelidikan ke Komnas HAM hingga 2019, padahal telah lewat tenggang waktu penyidikan yang diatur dalam UU Pengadilan HAM. Permasalahan penegakan pelanggaran HAM berat, tidak hanya sebatas masalah normatif, namun juga berkaitan dengan penerapan. Alasan yang mengemuka adanya pengembalian, selalu berputar pada kurangnya alat bukti yang mendukung. Hal tersebut, menunjukan tersendatnya korban untuk memperoleh keadilan dalam pelanggaran HAM berat. Berdasarkan hal tersebut, perlu memikirkan kembali aspek kewenangan yang diberikan pada dua lembaga yang berbeda kekuasaan dalam melakukan penyelidikan, penyidikan dan penuntutan.

Upaya pembenahan terhadap kelembagaan beserta kewenangan, harus terus dilakukan. Sampai hari ini, buntunya akses keadilan kepada korban sudah digagas melalui beberapa upaya, mulai dari dibentuknya komisi rekonsiliasi, dan pemindahan kewenangan penyidikan, dan penuntutan dari Jaksa Agung kepada Komnas HAM, seperti yang dilakukan oleh Komisi Pemberantasan Korupsi, dalam penegakan hukum tindak pidana korupsi. Komnas HAM dan Jaksa Agung dalam prespektif kelembagaan dan konstitusi, disebut memiliki fungsi sebagai constitusional importance, yang fungsinya berkaitan dengan penegakan hukum dan kekuasaan kehakiman. Jimly Ashiddiqie menjelaskan, bahwa Jaksa Agung dan Komnas-HAM merupakan Organ Lapis Kedua, yang mendapatkan kewenangan 
dari UUD, dan kewenangannya dari UU. ${ }^{10}$ Sebagai organ lapis kedua, maka keberadaannya merupakan penunjang terhadap organ lapis pertama, ${ }^{11}$ yang dalam hal ini adalah Kekuasaan Kehakiman, yang berkaitan dengan penegakan hukum. Tulisan ini akan fokus pada upaya pembenahan yang kedua, yakni menata ulang kewenangan penyidikan dan penuntutan dalam bentuk memindahkannya kepada Komnas HAM.

Dalam bahasa Satjipto Rahardjo, pembenahan kelembagaan dan kewenangan, adalah upaya membenahi struktur dalam negara hukum, yang merupakan proyek raksana yang harus terus dibangun, ${ }^{12}$ guna mencapai peradaban baru yang suci, dari bayang kelam masa lalu. Sebagai negara hukum, sesuai dengan Pasal 1 ayat (3) Undang-Undang Dasar Negara Republik Indonesia 1945 (UUD NRI 1945) wajib memberikan perlindungan terhadap hak asasi manusia. Kewajiban tersebut, merupakan tanggung jawab negara, yang ditegaskan kembali dalam Pasal 28I ayat (4) UUD NRI 1945: Perlindungan, pemajuan, penegakan, dan pemenuhan hak asasi manusia adalah tanggung jawab negara, terutama pemerintah. Sebagai dasar yang bersifat abstrak, tentu UUD NRI 1945 tidak memberikan penjelasan cakupan-cakupan secara deskriptif mengenai kewajiban dan tanggung jawab negara. Perlu kiranya merujuk kepada pendapat Ida Elisabeth Koch, kewajiban negara terhadap hak asasi manusia, adalah to respect, to protect dan to fulfill. Selanjutnya ia menjelaskan: ${ }^{13}$

"The obligation to respect requires the state to abstain from doing anything that violates the integrity of the individual or infringes on her or his freedom, including the freedom to use the material resources available to that individual in the way she or he findsbest to satisfy basic needs.

The obligation to protect requires from the state the measures neccesary to prevent other individuals or groups from violating the integrity, freedom of

10 Jimly Ashiddiqie, Konstitusi Bernegara Praksis Kenegaraan Bermartabat dan Demokratis, Setara Press, Malang, 2015, hlm., 169.

11 Organ Lapis pertama, adalah organ yang kewenangannya diberikan oleh konstitusi secara tegas, serta disebut sebagai lembaga tinggi negara.

12 Satjipto Rahardjo, Negara Hukum yang Membahagiakan Rakyatnya, Genta Publishing, Yogyakarta, 2009, hlm., 14.

13 Ida Elisabeth Koch, Human Rights as Indivisible Rights-The Protection of Socio Economic Demands Under Ther European Convention on Human Rights, Martinus Nijhoff Publishers, Leiden, Boston, 2009, hlm., 74-75 
action, or other human rights of the individual including the prevention of infringements of his or her material resources.

The obligation to fulfill requires the state to take the measures neccesary to ensure for each person within its jurisdiction opportunities to abstain satisfaction of those needs, recognised in the human rights instruments, which cannot be secured by personal efforts."

Atas beberapa penjabaran tersebut, negara memiliki kewajiban dan tanggung jawab penuh untuk memuntaskan pelanggaran HAM berat lalu. Penuntasan tersebut tentu harus ditunjang dengan kelembagaan dan sistem yang kokoh, tanpa itu, angan-angan untuk menghapus bayangan kelam masa lalu.

Berdasarkan uraian latar belakang tersebut, maka rumusan masalah dalam penelitian ini adalah bagaimana penegakan pelanggaran HAM berat yang dilakukan oleh komnas HAM dan Jaksa Agung? Bagaimana desain penataan ulang kewenangan penyelidikan, penyidikan, dan penuntutan pelanggaran HAM berat di masa mendatang?

Tulisan ini merupakan penelitian argumentasi hukum dengan memfokuskan ciri utama mengkaji pemberlakuan suatu kasus dengan disertai argumentasi/pertimbangan hukum yang dibuat penegak hukum, serta interpretasi di balik pemberlakuan tersebut. ${ }^{14}$ Penelitian ini dilakukan dengan penelitian doktrinal/normatif. Penelitian doktrinal/normatif adalah penelitian yang meletakkan hukum sebagai sebuah bangunan sistem norma, yang terdiri dari asas-asas, norma, kaidah dari peraturan perundangan, putusan pengadilan, perjanjian serta doktrin (ajaran). ${ }^{15}$ Penelitian normatif ini dilakukan dengan mengkaji dan menaganalisa peraturan perundang-undangan ataupun bahan hukum lain yang berkaitan dengan sistem peradilan HAM di Indonesia.

\section{Pembahasan}

\section{Penegakan Hukum Pelanggaran Ham Berat Yang Dilakukan Oleh Komnas HAM dan Jaksa Agung}

14 M.V. Hoecke, Legal doctrine: Which method(s) for what kind of discipline?, Hart Publishing, Oxford, 2011, hlm., 4.

15 Depri Liber Sonata, Hukum Normatif dan Empiris: Karakteristik Khas Dari Metode Meneliti Hukum, Lex crimen, Volume 8, No. 1, 2017, hlm., 25. 
Dalam hal terdapat peristiwa yang timbul dalam masyarakat yang diduga terdapat pelanggaran HAM yang berat ataupun terdapat laporan dari masyrakat akan adanya pelanggaran HAM yang berat, maka akan dilakukannya penyelidikan oleh Komnas HAM. ${ }^{16}$ Mengacu pada penjelasan Pasal 18 ayat (1) UU Pengadilan HAM, alasan kewenangan penyelidikan hanya dilakukan oleh Komnas HAM adalah untuk menjaga objektivitas hasil penyelidikan karena lembaga Komnas HAM dianggap sebagai lembaga yang bersifat independen. Seperti telah diajabarkan di atas, bahwa terdapat potensi yang besar, bahwa pelanggaran HAM berat dilakukan oleh aparatur negara itu sendiri, sehingga diperlukan suatu lembaga yang independen, yang tidak diintervensi oleh negara untuk melakukan penyelidikan terkait pelanggaran HAM berat. Bahkan, bila dirasa perlu, untuk meningkatkan peran masyrakat dalam penegakkan hukum yang benar-benar bebas dari intervensi dari pemerintah, sesuai dengan Pasal 18 ayat (2) UU UU Pengadilan HAM, maka Komnas HAM dalam melakukan penyelidikan dapat membentuk tim ad hoc yang terdiri atas Komnas HAM dan unsur masyarakat. Tentunya unsur masyarakat yang dimaksud adalah tokoh dan anggota masyarakat yang profesional, berdedikasi, berintegritas tinggi, dan menghayati di bidang hak asasi manusia. ${ }^{17}$

Hal ini tentunya untuk menjamin bahwa, selain partisipatif, namun penegakkan hukum terkait pelanggaran HAM berat, juga tetap dapat dijalankan secara professional. Dalam Pasal 19 UU Pengadilan HAM, dijelaskan kewenangan Komnas HAM, selaku penyelidik antara lain:

a) melakukan penyelidikan dan pemeriksaan terhadap peristiwa yang timbul dalam masyarakat yang berdasarkan sifat atau lingkupnya patut diduga terdapat pelanggaran hak asasi manusia yang berat;

b) menerima laporan atau pengaduan dari seseorang atau kelompok orang tentang terjadinya pelanggaran hak asasi manusia yang berat, serta mencari keterangan dan barang bukti;

16 Pasal 18 ayat (1) Undang-Undang Nomor 26 Tahun 2000 Tentang Pengadilan Hak Asasi Manusia.

17 Penjelasan Pasal 18 ayat (2) Undang-Undang Nomor 26 Tahun 2000 Tentang Pengadilan Hak Asasi Manusia. 
c) memanggil pihak pengadu, korban, atau pihak yang diadukan untuk diminta dan didengar keterangannya;

d) memanggil saksi untuk diminta dan didengar kesaksiannya;

e) meninjau dan mengumpulkan keterangan di tempat kejadian dan tempat lainnya yang dianggap perlu;

f) memanggil pihak terkait untuk memberikan keterangan secara tertulis atau menyerahkan dokumen yang diperlukan sesuai dengan aslinya;

g) atas perintah penyidik dapat melakukan tindakan berupa:

1. pemeriksaan surat;

2. penggeledahan dan penyitaan;

3. pemeriksaan setempat terhadap rumah, pekarangan, bangunan, dan tempat-tempat lainnya yang diduduki atau dimiliki pihak tertentu;

4. mendatangkan ahli dalam hubungan dengan penyelidikan.

Meskipun penyelidikan dilakukan oleh Komnas HAM, untuk tetap menjamin adanya koordinasi antara Komnas HAM dengan Jaksa Agung yang merupakan penyidik, maka sesuai dengan Pasal 19 ayat (2) UU Pengadilan HAM, maka penyelidik wajib memberitahukan hal tersebut kepada penyidik. Dalam Pasal 20 ayat (1) UU Pengadilan HAM, jika terdapat bukti permulaan yang cukup ${ }^{18}$ telah terjadi peristiwa pelanggaran hak asasi manusia yang berat, maka kesimpulan hasil penyelidikan disampaikan kepada penyidik. Dalam 7 (tujuh) hari, pasca adanya kesimpulan oleh penyelidik, maka penyelidik wajib menyerahkan seluruh berkas kepada penyidik. Dalam hal penyidik, ketika menerima berkas penyelidikan berpendapat bahwa hasil penyelidikan masih kurang lengkap, maka penyidik wajib segera mengembalikan hasil penyelidikan tersebut kepada penyelidik (Komnas HAM) disertai petunjuk untuk dilengkapi

18 Dalam Pasal 10 Undang-Undang Nomor 26 Tahun 2000 Tentang Pengadilan Hak Asasi Manusia menjelaskan bahwa jika tidak ditentukan lain dalam Undang-undang ini, hukum acara atas perkara pelanggaran hak asasi manusia yang berat dilakukan berdasarkan ketentuan hukum acara pidana, dimana dalam hukum acara pidana sesuai dengan putusan Mahkamah Konstitusi Nomor 21/PUU-XII/2014, bahwa bukti permulaan yang cukup harus dimaknai yaitu 2 alat bukti, selebihnya lihat Haposan Dwi Pamungkas Saragih, Penerapan Putusan Mahkamah Konstitusi Nomor 21/ PUU-XII/2014 Tentang Penetapan Tersangka Sebagai Objek Praperadilan," Lex Et Societas, Volume 4, No. 5, 2016, hlm., 52-53. 
dan dalam waktu 30 (tiga puluh) hari sejak tanggal diterimanya hasil penyelidikan, penyelidik wajib melengkapi kekurangan tersebut.

Meskipun penyelidikan dilaksanakan oleh Komnas HAM yang merupakan lembaga independen, namun terkait penyidikan tetap diserahkan kepada Jaksa Agung sesuai dengan Pasal 21 ayat (1) UU Pengadilan HAM. Ketika melihat lembaga penyelidik yang independen, sementara lembaga penyidik berasal dari Jaksa Agung, mungkin menimbulkan kebingungan terkait konsistensi untuk menjaga proses peradilan HAM berat yang independen. Namun, jika ditelisik, sejatinya ratio legis Pasal 21 ayat (1) UU Pengadilan HAM adalah karena penyelidikan merupakan proses pintu masuk untuk menentukan ada tidaknya pelanggaran HAM berat. Sehingga, ketika penyelidikan yang dianggap sebagai pintu masuk telah menetapkan seseorang dan/sekelompok orang, bahkan lembaga pemerintah telah melakukan pelanggaran HAM berat, maka diharapkan, Jaksa Agung, sebagai penyidik dapat meneruskan proses peneyelidikan tersebut.

Dalam Pasal 22 UU Pengadilan HAM, dijelaskan bahwa penyidikan wajib diselesaikan paling lambat 90 (sembilan puluh) hari terhitung sejak tanggal hasil penyelidikan diterima dan dinyatakan lengkap oleh penyidik. Bila tidak cukup, maka jangka waktu dapat diperpanjang untuk waktu paling lama 90 (sembilan puluh) hari oleh Ketua Pengadilan HAM sesuai dengan daerah hukumnya. ${ }^{19}$ Jika perpanjangan waktu tersebut tidak cukup lagi, maka dapat penyidikan dapat diperpanjang lagi, hingga paling lama 60 (enam puluh) hari oleh Ketua Pengadilan HAM sesuai dengan daerah hukumnya. ${ }^{20}$ Apabila dalam jangka waktu yang telah diberikan, ternyata dari hasil penyidikan tidak diperoleh bukti yang cukup, maka wajib dikeluarkan surat perintah penghentian penyidikan oleh Jaksa Agung. ${ }^{21}$

Setelah penyidikan selesai, maka akan dilanjutkan kepada tahap penuntutan. Tentunya penuntutan ini dilaksanakan juga oleh Jaksa Agung sesuai dengan Pasal 23 ayat (1) UU UU Pengadilan HAM. Dalam Pasal 24 UU Pengadilan

\footnotetext{
19 Pasal 22 ayat (2) Undang-Undang Nomor 26 Tahun 2000 Tentang Pengadilan Hak Asasi Manusia.

20 Pasal 22 ayat (3) Undang-Undang Nomor 26 Tahun 2000 Tentang Pengadilan Hak Asasi Manusia.

21 Pasal 22 ayat (4) Undang-Undang Nomor 26 Tahun 2000 Tentang Pengadilan Hak Asasi Manusia.
} 
HAM dijelaskan bahwa penuntutan wajib dilaksanakan paling lambat 70 (tujuh puluh) hari terhitung sejak tanggal hasil penyidikan diterima.

Meskipun secara normatif terdapat ketentuan terkait tenggang waktu proses peradilan HAM berat, namun ternyata dalam pengimplementasiaan, pasalpasal tersebut seolah tidak berarti. Hal ini terutama bisa dilihat dari kasus-kasus terkait pelanggaran HAM berat yang diselidiki oleh Komnas HAM, namun acapkali dikembalikan oleh Jaksa Agung dengan dasar bawah berkas-berkas penyelidikan tak memenuhi persyaratan formil dan materiil untuk kelengkapan berkas perkara. Berikut kasus-kasus pelanggaran HAM berat di era reformasi, yang diselidik oleh Komnas HAM, namun selalu dikembalikan oleh Jaksa Agung:

\section{a) Kasus Wasior}

Kasus Wasior terjadi pada 13 Juni 2001. Saat itu aparat Brimob Polda Papua menyerbu Desa Wonoboi, Wasior, Manokwari, Papua. Penyerbuan dipicu terbunuhnya 5 anggota Brimob dan seorang sipil di PT Vatika Papuana Perkasa. $^{22}$ Dari hasil penyelidikan Komnas HAM atas peristiwa ini ditemukan bahwa terdapat dugaan pelanggaran HAM berat yang mengakibatkan empat warga sipil meninggal dunia, 39 luka, 5 orang jadi korban penghilangan paksa dan 1 orang jadi korban kekerasan seksual. ${ }^{23}$ Pada tahun 2004 Tahun 2004, Kejaksaan Agung juga sudah melimpahkan berkas penyelidikan kasus itu ke tahapan penyidikan dan penuntutan. Berkas itu hanya sempat dua kali bolak-balik dari Komnas HAM ke Kejaksaan Agung. ${ }^{24}$ Tahun 2008, Komnas HAM sudah menyerahkan berkas penyelidikan tersebut kembali ke Kejaksaan Agung. Namun dikembalikan lagi oleh Jaksa Agung. Mengenai berkas tersebut kemudian dikembalikan lagi, hingga akhirnya 2018, berkas tersebut kembali dikembalikan oleh Jaksa Agung dengan alasan bahwa berkas tersebut tidak lengkap secara formail dan materil.

2 Budiarti Utami Putri, "Komnas HAM Sebut Kasus Wasior Wamena Paling Bisa Segera Diproses”. https://nasional.tempo.co/read/1154059/komnas-ham-sebut-kasus-wasiorwamena- paling-bisa-segera-diproses/full\&view=ok, diakses 6 Juni 2019.

23 Fabian Januarius Kuwado, "17 Tahun Tragedi Wasior, Kontras Nilai Pemerintahan Jokowi Belum Lakukan Apa-apa", https://https://nasional.kompas.com/read/2018/06/14/ 10463971/17-tahun-tragedi-wasior-kontras-nilai-pemerintahan-jokowi-belum-lakukan-apa. Diakses 6 Juni 2019.

24 Id. 


\section{b) Kasus Wamena}

Peristiwa Wamena terjadi pada 4 April 2003 saat masyarakat sipil Papua sedang merayakan Paskah. Namun saat itu aparat melakukan penyisiran di 25 kampung. ${ }^{25}$ Penyisiran berawal dari sekelompok masa tak dikenal membobol gudang senjata Markas Kodim 1702/Wamena. Saat penyerangan itu dua anggota Kodim tewas. Adapun setelah penyisiran 25 kampung, dilaporkan 9 tewas dan 38 orang luka berat. Pada bulan Juli 2004, Komisi Nasional Hak Asasi Manusia telah mengeluarkan laporan penyelidikan Projusticia atas dugaan adanya kejahatan terhadap Kemanusiaan untuk kasus Wamena, 4 April 2003. Kasus tersebut dilaporkan setelah terbunuhnya 9 orang, serta 38 orang luka beratdan cacat, selain itu terjadi pula pemindaan secara paksa terhadap Penduduk 25 Kampung. menyebabkan 42 orang meninggal dunia karena kelaparan, serta 15 orang korban perampasan kemerdekaan secara sewenangwenang. Komnas HAM juga menemukan pemaksaan penanda tanganan surat pernyataan, serta perusakan fasilitas umum, (gereja, Poliklinik, Gedung Sekolah mengakibatkan pengungsian penduduk secara paksa. Namun, sama seperti kasus Wasior, hasil penyelidikan dari Komnas HAM terus dikembalikan, hingga Desember 2018 dengan alasan berkas tidak lengkap secara formil dan materil.

\section{c) Kasus Jambu Kepok}

Peristiwa Jambu Keupok merupakan tragedi kemanusiaan yang terjadi pada 17 Mei 2003 setelah Daerah Operasi Militer (DOM), sebelum Darurat Militer di Aceh. Peristiwa ini merupakan bagian dari tindakan aparat TNI yang mencari anggota GAM di Jambu Keupok, Kecamatan Kota Bahagia, Aceh Selatan. Operasi itu menyebabkan 16 orang tewas karena tertembak dan terbakar. Ada juga terjadi penyiksaan terhadap 21 orang. Komnas HAM pun menurunkan Tim ad hoc untuk menyelidiki kasus tersebut. Hasilnya, terdapat bukti permulaan yang bisa menjadi

25 Kontras Papua, "Pres Release 12 Tahun peristiwa Wamena 4 April 2003", http://www.tapol.org/id/news/pres-release-12-tahun-peristiwa-wamena-4-april-2003, diakses 6 Juni 2019. 
dasar penetapan peristiwa tersebut sebagai pelanggaran HAM berat. ${ }^{26}$ Berkas tersebut diserahkan pada Agustus 2018, namun kasus tersebut dikembalikan dengan alasan berkas tidak lengkap secara formil dan materil.

Berdasarkan sejumlah kasus yang dijabarkan tersebut, bisa dilihat bahwa Jaksa Agung selalu mengembalikan berkas tersebut, dengan alasan tidak lengkap secara formil dan materil, namun tidak adanya keterangan atau petunjuk baru terkait kasus-kasus pelanggaran HAM berat yang dikembalikan, ini seolah Kejagung tidak ingin melakukan penyidikan terhadap kasus-kasus pelanggaran HAM berat dengan mengatakan kurang lengkap secara formil ataupun materil, namun tidak menerangkan secara detail bagian mana yang kurang lengkap. ${ }^{27}$

\section{Ragam Permasalahan: Telaah Terhadap Penelantaran}

Sebelumnya telah dijabarkan beberapa pelanggaran HAM berat yang terjadi, dan bagaimana penegakannya. Rupanya masalah utama, adalah penelantaran terhadap perkara. Hingga detik ini, belum satupun terbentuk Pengadilan HAM yang mengadili pelanggaran HAM berat tersebut, tentu semua itu ada di tangan Kejaksaan RI yang berwenang melakukan penuntutan, karena tanpa Penuntutan tersebut, Pengadilan HAM tidak mungkin bergulir.

Terhadap permasalahan penelantaran tersebut, penulis memetakan masalah mengenai sebab adanya penelantaran tersebut, yakni masalah kelembagaan dan masalah sistem. Pertama, masalah kelembagaan. Terjadi "lintas kekuasaan" dalam pra adjudication pelanggaran HAM berat, yakni antara komisi independen dengan kekuasaan eksekutif. Komnas-HAM merupakan bagian dari komisi independen negara, yang terlepas dari kekuasaan manapun. Ia bersifat mandiri dan merdeka dalam melaksanakan tugas dan kewenangan. Namun dalam penegakan pelanggaran HAM berat, Komnas-HAM dipaksa untuk berkolaborasi

26 Harian Rakyat Merdeka, "Hasto Atmojo Suroyo: Disiksa, Korban Tragedi Jambu Keupok Berharap Ada Kompensasi Ganti Rugi”, https://www.rmol.co/amp/2016/08/25/ 258263/Hasto-Atmojo-Suroyo:-Disiksa,-Korban-Tragedi-Jambu-Keupok-Berharap-AdaKompensasi-Ganti-Rugi-, diakses 6 Juni 2019.

27 Devina Halim, "Komnas HAM Kirim Balik 7 Berkas Perkara Pelanggaran Berat HAM ke Kejagung", https://nasional.kompas.com/read/2019/02/20/07021381/komnas-ham-kirimbalik-7-berkas-perkara-pelanggaran-berat-ham-ke-kejagung, diakses 6 Juni 2019 
dengan Kejaksaan RI yang bersifat lintas kekuasaan. Pada lintas kekuasaan inilah, sering terjadi beberapa aspek non-tekhnis seperti, tidak adanya kesatuan frame penegakan pelanggaran HAM berat antara Komnas-HAM dan Kejaksaan. Alhasil tidak sekali-dua kali berkas hasil penyelidikan yang diajukan oleh Komnas-HAM, dimentahkan oleh Kejaksaan. Tidak ada kesatuan integral visi-misi kelembagaan yang menaungi penegakan Pelanggaran HAM berat, sehingga hal ini menimbulkan ketegangan antar instansi. Penegakan pelanggaran HAM berat, tidak ada dalam satu track kelembagaan. Keadaan ini seolah menjadikan penyematan independen terhadap Komnas-HAM, banyak mengalami problem kegagalan dalam memberi makna luas bagi publik. ${ }^{28}$

Lintas kekuasaan, berpotensi memiliki pemahaman sendiri-sendiri, sehingga sering terjadi perbedaan antara lembaga yang satu dengan lembaga yang lain. Dalam proses penanganan pelanggaran HAM Berat yang menggunakan instrumen hukum acara pidana, perbedaan pemahaman berdampak terhadap standar kerja, sehingga proses dari suatu tahapan ke tahapan lain menimbulkan gesekan, seperti yang terkait hubungan fungsional antara penyelidik ke penyidikpenuntut umum. Akibat selanjutnya adalah munculnya instansi centris yang bergeser dari tujuan koordinasi penanganan perkara. Hal ini dijelaskan oleh Alan Cofey, menurutnya: ${ }^{29}$

"Criminal justice can function systematically only to degrees that each segment of the system takes into account all other segment. In the absence of functional relationship betwens segments, the criminal justice system is vulnerable to fragmentation and ineffetiveness. (Peradilan pidana dapat berfungsi secara sistematis hanya apabila masing-masing bagian dari sistem tersebut saling memperhitungkan satu sama lain. tidak adanya hubungan yang berfungsi secara baik antara masing-masing bagian mengakibatkan sistem peradilan pidana rentan terhadap perpecahan dan ketidak-efektifan)."

28 Zainal Arifin Mochtar, Lembaga Negara Independen - Dinamika Perkembangan dan Urgensi Penataannya Kembali Pasca Amandemen Konstitusi, PT. Raja Grafindo Persada, Jakarta, 2016, hlm., 72

29 Dalam Supriyanta, dikutip oleh Marwan Effendy, Teori Hukum dari Prespektif Kebijakan, Perbandingan, dan Harmonisasi Hukum Pidana, Gaung Persada Press Group, Jakarta, 2014, hlm., 394. 
Terjadi contradictio interminis dalam UU Pengadilan HAM. Mengacu pada penjelasan Pasal 18 ayat (1) UU Pengadilan HAM, alasan kewenangan penyelidikan hanya dilakukan oleh Komnas HAM adalah untuk menjaga objektivitas hasil penyelidikan karena lembaga Komnas HAM dianggap sebagai lembaga yang bersifat independen. Tetapi, spirit dari penjelasan pasal tersebut, tidak didukung oleh pelembagaan penyidik dan penuntutan, yang dilakukan oleh Jaksa Agung. Artinya, independensi penanganan pelanggaran HAM berat dalam UU a quo, masih bersifat setengah hati.

Kedua, masalah sistem (hukum acara). Ketiadaan hukum acara sendiri yang lengkap, menimbulkan persepsi di kalangan penyidikan (Kejaksaan), bahwa penyelidik (Komnas-HAM) menurut UU Pengadilan HAM merupakan sub-sistem penyidikan sebagaimana diatur KUHAP, dan bukan fungsi yang independen dari fungsi penyidikan. Dengan persepsi demikian, maka penyelidik (Komnas-HAM) harus menuruti semua kehendak penyidik apabila penyelidik tidak ingin hasil penyelidikannya tidak ditindaklanjuti oleh penyidik. Mantan Sekjen Komnas-HAM, Asmara Nababan mengatakan bahwa UU Pengadilan HAM mengandung banyak kelemahan, dengan mengutip pendapat dari David Cohen, persoalan pengadilan HAM tidak sebatas peraturan dan pengetahuan hakim atas peraturan itu. namun lebih kepada independensi dan imparsialitas aparat penegak hukumnya. ${ }^{30}$

Dalam pasal 20 ayat (3) UU Pengadilan HAM dinyatakan bahwa "Dalam hal penyidik (Kejaksaan) berpendapat bahwa hasil penyelidikan sebagaimana dimaksud dalam ayat (2) masih kurang lengkap, penyidik segea mengembalikan hasil penyelidikan tersebut kepada penylidik disertai dengan petunjuk untuk dilengkapi dan dalam waktu 30 hari sejak tanggal diterimanya hasil penyelidikan, penyelidik wajib melengkapi kekurangan tersebut". UU Pengadilan HAM hanya menetapkan batas waktu perlengkapan dan penyampaian kembali hasil penyelidikan kepada penyidik, yaitu 30 hari. Tetapi UU Pengadilan HAM tidak menetapkan waktu bagi penyidik untuk mengembalikan hasil penyelidikan kepada penyelidik, apabila dalam hal penyidik menganggap bahwa pengembalian

30 Suparman Marzuki, Tragedi Politik Hukum dan HAM, Pustaka Pelajar, Yogyakarta, 2011, hlm., 341 
harus dilakukan segera. Dengan tidak adanya batas waktu, maka peluang perkara menjadi terlantar sangat besar. Seperti contoh, hasil penyelidikan 13 September 1999 yang disampaikan Penyelidik (Komnas-HAM) kepada Penyidik pada 3 Maret 2004, dengan tanggapan sekitar 5,5 bulan, kemudian dikembalikan oleh Penyidik karena dianggap kurang lengkap. Kemudian, hasil penyelidikan peristiwa Wasior 2001-2002 dan Wamena 2003, disampaikan oleh penyelidik kepada penyidik pada 3 September 2004, baru dikembalikan dengan alasan kurang lengkap kepada penyelidik pada 30 Novembver 2004 (sekitar 3 bulan). ${ }^{31}$

\section{Penataan Ulang Kewenangan Penyelidikan, Penyidikan, Dan Penuntutan Pelanggaran Ham Berat Di Masa Mendatang}

Pelanggaran HAM berat adalah suatu bentuk perbuatan jahat yang bertentangan dari jus cogens. Istilah jus cogens dapat ditemukan dalam literatur hukum menyangkut kejahatan internasional. Eddy OS. Hiariej yang mengutip M. Cherif Bassiouni, membagi tingkatan kejahatan internasional menjadi: ${ }^{32}$

1. Kejahatan internasional yang disebut dengan "international crimes" adalah bagian dari jus cogens. Tipikal dan karakter "international crimes" berkaitan dengan perdamaian dan keamanan manusia serta nilai-nilai kemanusiaan yang fundamental. Termasuk dalam "international crimes" antara lain genosida, kejahatan terhadap kemanusiaan dan kejahatan perang;

2. Kejahatan internasional yang disebut dengan "international delict". Tipikal dan karakter "international delict" berkaitan dengan kepentingan internasional yang dilindungi meliputi lebih dari satu negara. Termasuk dalam "international delict" adalah pembajakan pesawat udara, pembiayaan terorisme, perdagangan obat-obatan terlarang secara melawan hukum, dan kejahatan terhadap petugas PBB;

3. Kejahatan internasional yang disebut dengan "international infraction". Dalam hukum pidana internasional secara normatif "international infraction" tidak termasuk "international crimes" dan "international delict". Kejahatan yang

31 Id, hlm., 342

32 Eddy OS Hiariej, supra no 6, hlm., 3-4. 
tercakup dalam "international infraction" antara lain pemalsuan dan peredaran uang palsu serta penyuapan terhadap pejabat publik asing.

Menggunakan pendapat M. Cherif Bassiouni, maka Pelanggaran HAM berat yang termaktub dalam hukum positif Indonesia, tergolong menjadi international crimes. Sebagai suatu kejahatan, maka penegakan hukum terhadapnya tidak bisa dilepaskan dari prinsip-prinsip dalam hukum pidana dan hukum acara pidana. Dalam aspek hukum pidana, pelanggaran HAM berat tergolong menjadi suatu kejahatan. Van Hamel menjelaskan: ${ }^{33}$

“...... het samenstel van de beginselen en regelen, welke de staat volgt, inzoover hij, als handhaver der openbare rechtsorde, onrecht verbieedt $e$ naan de overtreding zijner rechtsvoorschriften voor den ovetreder een bijsonder leeds als straf verbindt" (suatu keseluruhan dari asas-asas dan aturan-aturan yang ditaati negara (atau masyarakat hukum umum lainnya) yang mana mereka adalah pemelihara ketertiban hukum telah melarang perbuatan-perbuatan yang bersifat melanggar hukum dan telah mengaitkan pelanggaran terhadap aturan-aturan dengan suatu penderitaan yang bersifat khusus berupa pidana)

Sebagai suatu kejahatan yang terjadi dalam yurisdiksi negara Indonesia, maka penegakannya menggunakan Hukum acara pidana. Sebagaimana ditegaskan dalam Pasal 10 Undang-Undang Pengadilan HAM: "Dalam hal tidak ditentukan lain dalam Undang-undang ini, hukum acara atas perkara pelanggaran hak asasi manusia yang berat dilakukan berdasarkan ketentuan hukum acara pidana". Lebih lanjut, maka dalam penanganan pelanggaran HAM Berat, dimulai sejak tahap penyelidikan, penyidikan, penuntutan, dan pengadilan, yang dilakukan oleh masing-masing instansi penegak hukum yang memiliki kewenangan. ${ }^{34}$

Kewenangan Penyelidikan, dalam hal ini diatur dalam Pasal 20 UU Pengadilan HAM, yakni: ${ }^{35}$

33 G. A Van Hamel (1913), dalam Eddy Os. Hiariej. Prinsip-Prinsip Hukum Pidana. Cahaya Atma Pustaka, Yogyakarta, 2016, hlm., 15.

34 Kewenangan merupakan bagian dari kekuasaan, karena pada hakikatnya kewenangan adalah kekuasaan yang dilembagakan, (institutionalized power) atau kekuasasan yang diabsahkan atau kekuatan formal (formal power). Kewenangan merupakan kekuasaan yang diperoleh secara konstitusional. Bambang Waluyo, Penegakan Hukum di Indonesia, Sinar Grafika, Jakarta, 2016, hlm., 211.

35 Keberadaan pasal ini pernah diuji di Mahkamah Konstitusi, melalui Putusan Nomor 75/PUUXIII/2015 menolak permohonan pemohon, dan MK menyatakan pasal tersebut konstitusional. 
1. Dalam hal Komisi Nasional Hak Asasi Manusia berpendapat bahwa terdapat bukti permulaan yang cukup telah terjadi peristiwa pelanggaran hak asasi manusia yang berat, maka kesimpulan hasil penyelidikan disampaikan kepada penyidik.

2. Paling lambat 7 (tujuh) hari kerja setelah kesimpulan hasil penyelidikan disampaikan, Komisi Nasional Hak Asasi Manusia menyerahkan seluruh hasil penyelidikan kepada penyidik.

3. Dalam hal penyidik berpendapat bahwa hasil penyelidikan sebagaimana dimaksud dalam ayat (2) masih kurang lengkap, penyidik segera mengembalikan hasil penyelidikan tersebut kepada penyelidik disertai petunjuk untuk dilengkapi dan dalam waktu 30 (tiga puluh) hari sejak tanggal diterimanya hasil penyelidikan, penyelidik wajib melengkapi kekurangan tersebut.

Kewenangan Penyidikan terhadap pelanggaran HAM berat dilakukan oleh instansi yang berbeda, yakni oleh Jaksa Agung, sebagaimana diamanatkan dalam pasal 21 ayat (1) UU Pengadilan HAM: "Penyidikan perkara pelanggaran hak asasi manusia yang berat dilakukan oleh Jaksa Agung". Begitu pula terkait dengan Kewenangan Penuntutan, juga dilakukan oleh Jaksa Agung, sebagaimana diamanatkan dalam pasal pasal 23 ayat (1) UU Pengadilan HAM: "Penuntutan perkara pelanggaran hak asasi manusia yang berat dilakukan oleh Jaksa Agung”.

Atas penjabaran secara normatif dari masing-masing kewenangan tersebut, dapat dipahami: Pertama, dalam penegakan pelanggaran HAM berat, dilakukan oleh tiga instansi yang berbeda-beda, yakni Komnas-HAM, Jaksa Agung, dan Pengadilan HAM. Kedua, dalam tahap pra-adjudication (penyelidikan dan penyidikan-penuntutan) rupanya ditangani oleh dua instansi yang berbeda, yakni Komnas-HAM dan Kejaksaan RI (Penyidikan). Ketiga, tanpa adanya Penuntutan dari Kejaksaan, maka pengadilan HAM tidak akan digelar. Keempat, dua instansi ini tidak hanya berbeda kewenangan dalam penanganan pelanggaran HAM berat, tetapi juga berbeda rumpun kekuasaan. Komnas-HAM merupakan komisi 
independen ${ }^{36}$ dan Kejaksaan RI merupakan bagian dari Kekuasaan Eksekutif (Presiden dan Pemerintah). Pertanyaan paling mendasar, apakah penegakan pelanngaran HAM berat akan berjalan optimal, ketika ditangani oleh dua instansi yang berbeda kewenangan dan lintas kekuasaan? Itulah yang menjadi inti masalah dalam penelitian ini.

Namun sebelum menjawab itu, perlu kiranya untuk membaca ulang peran kejaksaan (penyelidikan dan penyidikan) yang dihadapkan dengan penanganan pelanggaran HAM berat. Hal paling utama yang harus dipahami adalah, dimensi pelanggaran HAM berat selalu dilakukan oleh aktor negara, yakni pemerintah yang memiliki kuasa dan mengendalikan alat-alat negara. Dalam penelitian disertasi Eddy OS. Hiariej mengenai pengadilan HAM berat di beberapa negara, menyatakan bahwa penindakan pelanggaran HAM berat dengan menggunakan instrumen hukum pidana tidaklah mudah, karena lebih bernuansa politik daripada masalah hukum. Disatu sisi, dalam konteks hukum pidana nasional, situasi politik suatu negara sangat mempengaruhi penindakan terhadap pelakunya, karena biasanya berkaitan erat dengan otoritarian suatu rezim. Muladi menjelaskan, pelanggaran HAM mempunyai nuansa khusus, yaitu adanya penyalahgunaan kekuasaan (abuse of power), artinya para pelaku bertindak dalam konteks pemerintah dan difasilitasi oleh kekuasaan pemerintah (commited within a governmental context and faciliated by government power). Perbuatan tersebut dilakukan di dalam atau berkaitan dengan kedudukannya (within or is a association with governemntal status). ${ }^{37}$ Artinya penegakan pelanggaran HAM berat selalu dihadapkan vis a vis dengan rezim yang berkuasa.

Kejaksaan (sebagai bagian dari pemerintah) adalah lembaga pemerintahan $^{38}$ dan memang ditafsirkan sebagai badan pemerintah yang melaksanakan kekuasaan eksekutif. Bagir Manan menjelaskan, dengan demikian pimpinannya juga adalah pimpinan dari suatu badan pemerintahan, yang

\footnotetext{
36 Yang dalam perkembangan tata negara, disebut sebagai state auxiliary bodie, seperti KPK, KPU, Bawaslu, dan komisi independen lainnya.

37 Muladi, dalam Andrey Sujatmiko, Hukum HAM dan Hukum Humaniter, PT Rajagrafindo Persada, Jakarta, 2015, hlm., 33.

38 Pasal 2 ayat 1 Undang-Undang Nomor 16 tahun 2004.
} 
merupakan kekuasaan eksekutif. Senada dengan hal itu, Marwan Effendi mengatakan, bila kedudukan Kejaksaan sebagai suatu lembaga pemerintahan dikaitkan dengan kewenangan Kejaksaan melakukan kekuasaan negara di bidang penuntutan secara merdeka, maka terdapat kontradiksi dalam pengaturannya (dual obligation). Dikatakan demikian, adalah mustahil Kejaksaan melaksanakan fungsi, tugas dan wewenangnya terlepas dari pengaruh kekuasaan pemerintah dan mungkin juga pengaruh kekuasaan lainnya, karena kedudukan Kejaksaan berada dibawah eksekutif. 39

Selama ini Kejaksaan dalam melaksanakan tugasnya kerap disinyalir lebih berorientasi kepada kepentingan kekuasaan ketimbangan kepentingan umum. Hal ini terjadi karena banyaknya intervensi pihak luar terhadap Kejaksaan, tidak hanya saat ini, sejak awal didirikannya Kejaksaan hal itu sudah terjadi. Tahun 1955, sewaktu Jaksa Agung dijabat oleh R. Soeprapto yang dikenal sebagai bapak Korps Kejaksaan, telah ada upaya-upaya sistematis untuk mempengaruhi Kejaksaan. Berbagai langkah dan kebijakan yang dilakukan Soeprapto untuk menegakkan wibawa Kejaksaan, justru dinilai oleh penguasa sebagai tindakan yang tidak sejalan dengan semangat revolusi. Pada saat yang bersamaan, justru ia dituduh oleh PKI sebagai antek Belanda lantaran membebasan seorang narapidana subversif berkewarganegaraan Belanda. Kemudian ia dicopot, dan diganti oleh Gatot Tanumihadja dari Partai Murba yang sangat mendukung konsep-konsep Suekarno seperti Manipol-Usdek.

Tidak hanya intervensi dari luar, dalam catatan Adnan Buyung Nasution ${ }^{40}$ terjadi gesekan antara Kejaksaan dengan Kepolisian RI, yang padahal sama-sama

39 Kejaksaan adalah satu-satunya lembaga dalam sistem peradilan pidana pada umumnya, yang tidak disebut dalam Konstitusi. Hal ini didasarkan pada tafsir argumentum a contrario Pasal 30 ayat (4) UUD 1945 yang menegaskan bahwa Kepolisian Negara Republik Indonesia sebagai alat negara yang menjaga keamanan dan ketertiban masyarakat bertugas melindungi, mengayomi, melayani masyarakat, serta menegakkan hukum. Kepolisian RI ditafsirkan sebagai alat negara, artinya diluar dari Kepolisian RI, merupakan bagian dari alat pemerintah. Hal ini semakin menegaskan bahwa, kedudukan Kejaksanaan secara konstitusional adalah bagian dari pemerintah. lebih lanjut, lihat dalam Marwan Effendy, Kejaksaan Republik Indonesia, Posisi, dan Fungsinya dari Prespektif Hukum, PT Gramedia Pustaka Utama, Jakarta, 2005, hlm., 125.

40 Adnan Buyung Nasution, Demokrasi konstitusional: Pikiran \& Gagasan, Penerbit Buku Kompas, Jakarta, 2010, hlm., 78. 
berada dalam rumpun kekuasaan eksekutif. Gesekan itu berbentuk tabrakan kepentingan kerap (yang mengatasnamakan kewenangan). Contohnya, yang terjadi di masa Jaksa Agung Singgih dan Polri di bawah kepemimpinan Jenderal Dibyo Widodo, yang berakibat dimungkinkannya Kepolisian turut mengusut kasus korupsi. Dahulu disfungsionalisasi Kejaksaan mencapai puncaknya ketika pada 22 Juli 1991 terbit Undang-Undang Nomor 5 tahun 1991 tentang Kejaksaan. Di dalam Pasal 2 ayat (1) UU $A$ quo dinyatakan bahwa Kejaksaan adalah lembaga Pemerintahan yang melaksanakan kekuasaan negara bidang penuntutan.

Dalam perkembangannya, meskipun terdapat beberapa problem yang berhujung pada revisi Undang-Undang Kejaksaan, rupanya pembentuk undangundang masih memposisikan Kejakksaan dalam koridor lembaga pemerintahan. Penulis menyandingkan antara undang-undang terbaru dengan sebelumnya:

\section{Tabel 2: Perbandingan undang-undang terbaru dengan sebelumnya}

\begin{tabular}{|c|c|}
\hline $\begin{array}{l}\text { Undang-Undang Nomor } 5 \text { Tahun } 1991 \\
\text { tentang Kejaksaan }\end{array}$ & $\begin{array}{l}\text { Undang-Undang Nomor } 16 \text { Tahun } 2004 \\
\text { tentang Kejaksaan }\end{array}$ \\
\hline Pasal 2 Ayat (1): & Pasal 2 Ayat (1): \\
\hline $\begin{array}{l}\text { Kejaksaan Republik Indonesia, selanjutnya } \\
\text { dalam Undang-undang ini disebut } \\
\text { kejaksaan, adalah lembaga pemerintahan } \\
\text { yang melaksanakan kekuasaan negara di } \\
\text { bidang penuntutan }\end{array}$ & $\begin{array}{l}\text { Kejaksaan Republik Indonesia yang selanjutnya } \\
\text { dalam Undang-Undang ini disebut kejaksaan } \\
\text { adalah lembaga pemerintahan yang } \\
\text { melaksanakan kekuasaan negara di bidang } \\
\text { penuntutan serta kewenangan lain berdasarkan } \\
\text { undang-undang. }\end{array}$ \\
\hline Pasal 2 Ayat (2): & Pasal 2 ayat (2): \\
\hline \multirow[t]{3}{*}{$\begin{array}{l}\text { Kejaksaan adalah satu dan tidak terpisah- } \\
\text { pisahkan dalammelakukan penuntutan. }\end{array}$} & $\begin{array}{l}\text { Kekuasaan negara sebagaimana dimaksud pada } \\
\text { ayat (1) dilaksanakan secara merdeka. }\end{array}$ \\
\hline & Pasal 2 ayat 3: \\
\hline & $\begin{array}{l}\text { Kejaksaan adalah satu dan tidak terpisah- } \\
\text { pisahkan dalammelakukan penuntutan. }\end{array}$ \\
\hline
\end{tabular}

Sumber: Diolah penulis dari berbagai sumber.

Tidak ada perbedaan signifikan antara kedua undang-undang tersebut, mengenai kedudukan Kejaksaan.

Membaca ulang peran (penyidikan-penuntutan) dan kedudukan Kejaksaan, lalu dihadapkan dengan penegakan pelanggaran HAM berat, rasanya begitu sulit mencapai hasil optimal. Lantaran dalam sistem penegakan pelanggaran HAM berat yang bernuansa politis, masih membuka celah adanya 
intervensi kekuasaan. Seperti di belahan dunia lain, banyak usaha untuk melakukan penuntutan dan menghukum mereka yang bertanggung jawab terhadap pelanggaran HAM berat, namun upaya itu selalu mengalami kegagalan. Dalam catatan Priscilla B. Hayner mengenai pengalaman penegakan pelanggaran HAM berat di El-Salvador, Afrika Selatan dan Chili, transisi politik pergantian rezim selalu terdapat kompromi politis yang mencakup imunitas dari penuntutan kepada para penindas masa lalu. Bahkan ada upaya mempertahankan kekuasaan mereka, atau melibatkan mereka (penindas/pelaku pelanggaran HAM berat) dalam pemerintahan yang baru. Ketika ada upaya untuk membuka kembali penegakan terhadap pelanggaran HAM berat di masa lalu, selalu terjadi pembatasan-pembatasan oleh rezim berkuasa, hingga sampai pada suatu keadaan frustasi para pencari keadilan. ${ }^{41}$

Tentunya pelembagaan penegakan pelanggaran HAM berat harus dibangun melalui pendekatan institusional dan sistem yang kuat, kokoh dan tertutup dari intervensi kekuasaan. Pelanggaran HAM berat dikualifikiasikan sebagai delicta jure gentium, (kejahatan terhadap hukum bangsa-bangsa) ${ }^{42}$ dan merupakan pengingkaran terhadap jus cogens (prinsip umum dalam hukum internasional berkaitan dengan moral). ${ }^{43}$ Pelanggaran HAM berat adalah masalah kemanusiaan yang secara prinsip merupakan masalah universal, bukan melulu menjadi masalah kajian suatu bidang ilmu tertentu. Itulah mengapa, kendatipun semua uraiannya menukik pada satu tema yang sama, namun pendekatan yang ditawarkan selalu multidimensi dengan karakter komprehensif, karena kekerasan yang terjadi pada masa lalu memiliki tingkat kerumitan tinggi, baik pada tataran teoritis maupun praktis.

Apapun kerumitannya, tentu dibutuhkan pertanggungjawaban setelah terjadinya kekejaman. Berjalannya waktu dan bergantinya rezim kekuasaan, tidak serta merta menguburkan apa yang sudah terjadi di masa lalu. Jika pelanggaran HAM berat dibiarkan, maka hal itu akan menjadi bom waktu yang bisa meledak

41 Priscilla B. Hayner, Unspeakable Truth-Facing The Challenge of Truth Commissions, Routledge, New York, London, 2002, hlm., 29-30

42 Eddy O.S Hiariej, Pengantar Hukum Pidana Internasional, Erlangga, Jakarta, 2009, hlm., 11.

43 Id, hlm., 12. 
setiap saat. Satjipto Rahardjo mengatakan, "Pembiaran terhadap masalah hukum, semakin menjauhkan penegakan hukum, dengan identitas utama hukum, yakni dimensi kemanusiaan hukum". ${ }^{44}$ Selain itu, pembiaran terhadap pelanggaran HAM berat akan menjadikan negara secara tanpa sadar menuju otoriterianisme, yang dalam catatan Steven Levitsky dan Daniel Ziblat, salah satu indikator perilaku otoriter adalah membiarkan tindakan kekerasan di masa lalu. ${ }^{45}$

\section{Politik Hukum dan Kelembagaan Penegakan Pelanggaran HAM berat di Masa Mendatang}

Bagir Manan menjelaskan, bahwa politik hukum tidak lain adalah kebijaksanaan yang akan dan sedang ditempuh mengenai penentuan isi hukum, pembentukan hukum, penegakan hukum, beserta segala urusan yang akan menopang pembentukan dan penegakan hukum tersebut. ${ }^{46}$ Secara internal, menurut Bagir Manan, ada tiga lingkup utama politik hukum,yaitu :

1. Politik pembentukan hukum;

2. Politik mengenai isi (asas dan kaidah) hukum; dan

3. Politik penegakan hukum.

Politik pembentukan hukum adalah kebijaksanaan yang bersangkutan dengan penciptaan, pembaruan dan pengembangan hukum. Politik pembentukan hukum seperti itu mencakup:

1. Kebijaksanaan (pembentukan) perundang-undangan;

2. Kebijaksanaan (pembentukan) hukum yurisprudensi atau putusan hakim dan

3. Kebijaksanaan terhadap peraturan tidak tertulis lainnya.

Politik mengenai isi hukum adalah kebijaksanaan agar asas dan kaidah hukum:

1. Memenuhi unsur filosofis, yuridis dan sosiologis;

44 Satjipto Rahardjo, Pendidikan Hukum sebagai Pendidikan Kemanusiaan: Kaitannya dengan Profesi Hukum dan Pembangunan Hukum Nasional, Genta Publishing, Yogyakarta, 2009, hlm., 23.

45 Steven Levitsky dan Daniel Ziblat, Bagaimana Demokrasi Mati-Apa yang Diungkapkan Sejarah tentang Masa Depan Kita, PT. Gramedia Pustaka Utama, 2019, hlm., 12.

46 Bagir Manan, Politik Perundang-Undangan Dalam Rangka Mengantisipasi Liberalisasi Ekonomi, Makalah Seminar Nasional tentang Perseroan Terbatas, Bandar Lampung, 1996, hlm., 2. 
2. Mencerminkan kebijaksanaan di bidang ekonomi, sosial, budaya,politik dan pertahanan-keamanan;

3. Mencerminkan tujuan dan fungsi hukum tertentu yang hendak dicapai;

4. Mencerminkan kehendak mencapai cita-cita berbangsa dan bernegara di bidang politik, ekonomi, sosial, budaya dan lain-lain.

Satjipto Rahardjo mejelaskan, bahwa hukum harus senantiasa melakukan penyesuaian terhadap tujuan-tujuan yang ingin dicapai oleh masyarakatnya. Dengan demikian, hukum mempunyai dinamika. Politik hukum merupakan salah satu faktor yang menyebabkan terjadinya dinamika yang demikian itu, karena ia diarahkan pada ius constitutum/hukum yang seharusnya berlaku. ${ }^{47} \mathrm{M}$. Solly Lubis menjelaskan pendekatan yang digunakan untuk menghadapi masalah-masalah dalam hukum, salah satunya yakni pendekatan sistem. ${ }^{48}$ Pendekatan sistem yakni pembinaan/pembangunan hukum nasional harus dilihat secara holistik, yang kontekstual dan konseptual bertalian erat dengan dimensi geo-politik, eko-politik, demo-politik, sosio-politik dan krato-politik. Artinya politik hukum dalam menghadap berbagai permsalahan tidak berdiri lepas, melainkan bertalian erat dengan dimensi lainnya. Pandangan yang mengatakan bahwa dimensi hukum itu berdiri sendiri, dan lepas dari dimensi lainnya, adalah pandangan yang sangat sempit dan menganggap hukum begitu ekslusif. Pandangan ini akhirnya menjadikan hukum tidak memiliki daya guna, dan daya manfaat tinggi. 49

Resiprokalitas politik dan hukum telah dibahas oleh beberapa ahli. Semisal oleh Philip Nonet dan Philip Selznick yang melihat adanya implikasi pada keterlibatan aktor-aktor negara dalam merumuskan hukum, termasuk kemudian hasil yang di dapatkan apakah merupakan produk hukum otonom, responsif dan fakultatif, atau sebaliknya, malah menjadi produk hukum yang menindas, imperatif, dan ortodoks. Tidak berbeda jauh dengan pandangan tersebut, pemikiran David Trubbeck yang hadir sebelumnya, menyebutkan bahwa tindakan

47 Satjipto Rahardjo, Ilmu Hukum, Kedelapan, Citra Aditya Bakti, Bandung, 2014, hlm., 397.

48 M. Solly Lubis, Politik dan Hukum di Era Reformasi, Penerbit Mandar Maju, Bandung, 2000, hlm., 23.

49 Pada konteks ini, politik hukum dimaknai sebagai strategi yang dirumuskan untuk menyelesaikan suatu permasalahan/tantangan yang dihadapi, dan strategi itu kemudian dituangkan dalam Peraturan Perundang-undangan. 
tersebut (keterlibatan aktor negara) disebut sebagai purposive human action, yang menenkan kan pembuatan dan penegakan hukum adalan instrumentasi dari putusan dan keinginan politik. 50

Atas beberapa penjelasan mengenai politik hukum tersebut, penulis berpendapat bahwa politik hukum adalah strategi yang dirumuskan untuk menuntaskan masalah-masalah hukum dan mencapai tujuan tertentu. stategi yang digunakan adalah strategi hukum. Perumusan dan pemilihan terhadap strategi tersebut tidak bisa dilakukan secara ekslusif, melainkan inklusif ke dalam disiplin dan dimensi non-hukum. Untuk merumuskan strategi tersebut, tentu harus dilakukan pembacaan secara utuh terhadap seluruh permasalahan yang ada.

Hal utama yang harus dibaca kembali dalam politik hukum, adalah mengenai patologi peradilan. Dalam cara kerjanya, cenderung tidak netral dan selalu menghalalkan segala cara. Pemeriksaan menunjuk kepada pelayanan status, biasanya memihak status lebih tinggi dan berkepentingan, dibandingkan status rendah dan kering bobot materinya. Perilaku diskriminatif dan tercela tumbuh subur dalam sistem peradilan, dan akhirnya melahirkan perlakuan berbeda terhadap segmen masyarakat tertentu. ${ }^{51}$ Marc Glanter mensinyalir, bahwa pihakpihak yang memiliki kemampuan lebih akan mendominasi praktik hukum, dimana yang mendominasi akan mendapatkan pelayanan yang lebih baik, lalu aparatur hukum (Polisi, Jaksa, dan sebagainya) harus bekerja dalam keadaan dominasi tersebut. Keadaan dominasi oleh orang memiliki status lebih tinggi, menjadikan badan aparatur hukum akan menjadi badan penegak hukum yang condong melindungi kepentingan atau kedudukan golongan tertentu, sekalipun cara umum segala sesuatunya dapat dikatakan sah/legal. Urusan legalitas hal yang mudah, namun apakah memiliki legitimasi keadilan, itulah yang masih terus harus dipermasalahkan. Pada proses dominasi tersebut, maka kepentingan, kelas, dan sumber otoritas menjadi satu. Keadaan ini serupa dengan apa yang dikatakan oleh

50 Zainal Arifin Mochtar, Lembaga Negara Independen - Dinamika Perkembangan dan Urgensi Penataannya Kembali Pasca Amandemen Konstitusi, PT. Raja Grafindo Persada, Jakarta, 2016, hlm., 61.

51 Anthon F. Susanto, Menuju Kejahatan Sempurna (Makna Simbolik Kekerasanan dalam Proses Peradilan Pidana). Dalam Muladi,eds., Hak Asasi Manusia- Hakikat, Konsep, dan Implikasinya Prespektif Hukum dan Masyarakat, Reflika Aditama, Bandung, 2009, hlm., 72. 
Daniel S. Lev, yakni "suatu sistem hukum terdiri atas proses formal, yang merupakan lembaga formal, berjalan bersama-sama dengan proses-proses informal. 52

Dunia ini tidak berhenti dan terus membuat sejarahnya sendiri. Sesudah menjalan era modern selama beberapa abad, sekarang kita tiba pada suatu pasa yang disebut sebagai era post- modernism (PM), karena sesudah sekian lama kita hidup dalam era modern, kemudian dirasakan ada sesuatu masa yang berbeda, yang tidak dapat, untuk disebut modern begitu saja. Pada intinya ada kemerosotan idealisme modern. Oleh karena itu PM ingin melihat kembali kesalahan-kesalahan dan cacat pemikiran serta praksis zaman modern itu. ${ }^{53}$ Salah satunya selalu yang menjangkit ke dalam sektor kekuasaan. Hukum dan peraturan perundangundangan yang berlaku tidak boleh ditetapkan dan diterapkan secara sepihak oleh dan atau hanya untuk kepentingan penguasa. Hal tersebut bertentangan dengan prinsip demokrasi. hukum tidak dimaksudkan untuk hanya menjamin kepentingan beberapa orang yang berkuasa, melainkan menjamin kepentingan keadilan bagi semua orang. Dengan demikian negara hukum yang dikembangkan bukan absolute rechstaat, melainkan democratische rechstaat. ${ }^{4}$

Kemerosotan idealisme itulah yang mengundang pemikiran baru terhadap adanya jenis kekuasaan baru, yakni kekuasaan independent yang didirikan dalam rangka menuntaskan apa yang tidak mampu diselesaikan oleh Kekuasaan induk. Secara sederhana dapat dikatakan lembaga negara merupakan konsekuensi logis dari pemisahan kekuasaan. Cabang kekuasaan yang terpisah tersebut, membutuhkan lembaga negara sebagai pelaksana dari cabang kekuasaan eksekutif, legislatif dan yudikatif. Oleh sebab itu kemudian, lahirlah lembagalembaga negara yang bekerja di bawah atau menunjang sistem masing-masing cabang kekuasaan. Artinya, lembaga-lembaga ini menjadi organ pelaksana/penunjang dari organisasi kekuasaan negara, yang dalam bahasa G.

\footnotetext{
52 Id, hlm., 73.

53 Satjipto Rahardjo, Hak Asasi Manusi a dalam Masyarakatnya. Dalam Muladi, eds., Hak Asasi Manusia, Hakikat, Konsep, dan Implikasinya Prespektif Hukum dan Masyarakat, Reflika Aditama, Bandung, 2009, hlm., 162.

54 Jimly Ashiddiqie dalam Suparman Marzuki, Tragedi Politik Hukum dan HAM, Pustaka Pelajar, Yogyakarta, 2011, hlm., 51.
} 
Jellineck merupakan contradiction in objecto. ${ }^{55}$ Jika negara tidak memiliki organorgan atau perlengkapan negara, maka ia menjadi tidak sesuai dengan sifat dan hakikat negara. singkatnya keberadaan lembaga-lembaga negara menjadi niscaya untuk mengisi dan menjalankan negara. ${ }^{56}$

Dari hal itulah Jellineck kemudian membagi lembaga negara menjadi dua golongan besar, yakni unmittelbareorgan (alat perlengkapan negara yang langsung) dan mittelbareorgan (alat perlengkapan negara yang tidak langsung). ${ }^{57}$ Unmittelbareorgan adalah organ yang diatur oleh konstitusi, yang memiliki peran sebagai penentu mittelbareorgan. Mittelbareorgan adalah organ yang keberadaannya bergantung pada Unmittelbareorgan, jika Unmittelbareorgan mampu menjalankan fungsi dan tugasnya, maka Mittelbareorgan tidak akan ada. Namun jika Unmittelbareorgan tidak mampi menjalankan fungsi dan tugasnya, maka Mittelbareorgan dibutuhkan dan akan dibentuk. Seperti contoh tindak pidana korupsi, semula tindak pidana korupsi dilaksanakan oleh Kepolisian RI (unmittelbareorgan), karena dirasa tidak berjalan secara efektif, maka pemberantasan tindak pidana korupsi diambil alih oleh Komisi Pemberantasan Korupsi (komisi independent-Mittelbareorgan). Keberadaan KPK bergantung58 kepada Kepolisian, jika dahulu Kepolisian dinilai efektif memberantas korupsi, maka KPK tidak mungkin ada. Karena dirasa Kepolisian tidak optimal, maka pemberantasan korupsi dialihkan kepada KPK. ${ }^{59}$

Jenis lembaga negara mengalami modifikasi kuat dan semakin beragam seiring dengan kehidupan bernegara yang semakin kompleks. Kompleksitas bernegara dipengaruhi oleh begitu banyak interaksi dengan masyarakat, serta kebutuhan yang semakin berkembang berakibat pada pergeseran peran negara yang membawa ke variasi lembaga negara yang kian membuncah. Rancang bangun kelembagaan negara mengalami perkembangan seiring dengan kebutuhan

Dalam Lukman Hakim, dikutip Oleh Zainal Arifin, supra no 50, hlm., 55.

Id, hlm, 52 .

Id, hlm, 54 .

8 Bergantung disini bukan dimaknai sebagai sub-ordinasi.

59 Konsideran Menimbang huruf B, Undang-Undang Nomor 30 Tahun 2002: bahwa lembaga pemerintah yang menangani perkara tindak pidana korupsi belum berfungsi secara efektif dan efisien dalam memberantas tindak pidana korupsi. 
masyarakat di suatu negara. Misalnya, guna menangani kasus tertentu, situasi transisi demorasi ataupun juga akibat ketidakpercayaan atas lembaga yang sudah ada. Oleh karenanya dibeberapa negara, menciptakan beberapa lembaga atau komisi negara sebagai penunjang utama (state auxiliary agencies), atau dalam bahasa Jellineck disebut Mittelbareorgan. ${ }^{60}$

Cornelis Lay ${ }^{61}$ mengatakan terdapat beberapa hal yang mempengaruhi kelahiran komisi negara: Pertama, keresehan negara terhadap ketidakpastian perlindungan individu dan marginal dari pejabat publik, maupun negara yang lain. Kedua, mencerminkan sentralitas negara sebagai otoritas publik, maupun warga negara yang lain. Ketiga, merupakan sebuah produk evolusi yang sifatnya incremental dan komplementer terhadap organ-organ kekuasaan yang hadir terdahulu, sebagai hasil pemilihan gagasan trias politica. Mengingat latar belakang tersebut, Philips J. Cooper62 telah mengingatkan besarnya tantangan yang akan dihadapi negara, kaitannya dengan pemerintahan. Tantangan itu berkaitan dengan permasalahan-permasalahan diversity, decentralization, privatization, civil society, democracy, accountability, reeingenring, hi-tech. Tantangan yang rupanya serupa dengan kondisi penegakan pelanggaran HAM berat, adalah diversity.

Tantangan diversity menjadi alasan besar untuk membangun lembagalembaga yang lebih menekankan pada penghargaan hak asasi manusia, kaum minoritas, dan prinsip kesetaraan. Latar belakang dari komisi independen, tentu menjadi faktor utama adanya penanganan pelanggaran HAM berat, yang juga diselesaikan oleh komisi independen. Faktor sosio-politik kekuasaan yang berada dalam rezim eksekutif, sangat memiliki pengaruh dalam penegakan pelanggaran HAM berat. Dalam uraian sebelumnya, independensi Komnas-HAM mengalami evolusi yang berjalan secara perlahan. Mulai dari pembentukan melalui Keppres, kemudian bermigrasi dasar hukum ke Undang-Undang, meskipun tidak diatur secara mandiri. 20 (dua puluh) tahun setelah UU HAM diundangkan, dan Komnas-

\footnotetext{
Zainal Arifin Mochtar, supra no 50, hlm., 61.

Zainal Arifin Mochtar, supra no 50, hlm., 63.

Zainal Arifin Mochtar, supra no 50, hlm., 64.
} 
HAM belum berhasil menunjukan taringnya, perubahan revolusioner sangat perlu dilakukan terhadap Komnas-HAM.

Setelah aspek kelembagaan, selanjutnya yang harus ditekankan dalam penegakan pelanggaran HAM berat, adalah pendekatan sistem, yang dalam hal ini adalah sistem peradilan pidana. Pelanggaran HAM berat yang menggunakan instrumen hukum pidana, tidak bisa dilepaskan dari aspek-aspek teoritis dari sistem peradilan pidana. Sistem Peradilan Pidana pertama-tama ditandai oleh adanya penerapan pendekatan administrasi di sepanjang proses peradilan pidana. Sistem Peradilan Pidana selanjutnya dilihat sebagai suatu hasil interaksi antara peraturan perundang-undangan, praktek administrasi dan sikap atau tingkah laku sosial. Pengertian sistem ini mengandung implikasi suatu proses interaksi, yang dipersiapkan secara rasional dan dengan cara efisien, untuk memberikan hasil tertentu dengan segala keterbatasannya. Sistem Peradilan Pidana juga dipahami sebagai mekanisme kerja dalam penanggulangan kejahatan dengan penggunaan dasar sistem. Mekanisme ini pada dasarnya merupakan hasil interaksi antara peraturan perundang-undangan, praktek administrasi peradilan pidana, sikap tingkah laku sosial, dan suatu sistem yang rasional, yang kesemuanya memberikan hasil tertentu dengan segala keterbatasannya. ${ }^{63}$

Sistem peradilan pidana menurut Andi Hamzah, memiliki dua peranan yang sangat penting yakni sebagai sebuah sistem dan sebagai sebuah proses. Sebagai sebuah sistem, sistem peradilan pidana dilihat dari terjalinya terjalinnya hubungan fungsional dan institusional yang bersifat kordinatif antara lembaga dan institusi yang masing-masing memiliki fungsi penegakan hukum. Dengan demikian, sistem peradilan pidana sebagai sebuah sistem meliputi penyidikan, penuntutan, persidangan dan pelaksanaan putusan hakim sebagai satu kesatuan sistem yang terintegrasi. Sedangkan dalam perannya sebagai sebuah proses, sistem peradilan pidana sebagai satu kesatuan proses penegakan hukum yang mengintegrasikan setiap proses-proses hukum yang ada dalam setiap tingkatan-

63 Anthon F. Susanto, dalam Armunanto Hutahaean, Erlyn Indarti, Lembaga Penyidik Dalam Sistem Peradilan Pidana Terpadu Di Indonesia, Jurnal Legislasi Indonesia Vol 16 No.1 - Maret 2019, hlm., 30. 
tingkatan. Sehingga dalam fungsi untuk melakukan penyidikan, penuntutan dan peradilan, maka integrasi yang dilakukan melalui integrasi sistem peradilan pidana melibatkan sub-sistem terkait yakni penyidik, jaksa penuntut umum, badan dan atau lembaga peradilan umum, penasehat hukum, bahkan lembaga pemasyarakatan. ${ }^{64}$

Hasil dari penanggulangan kejahatan, merupakan orientasi dari sistem peradilan pidana, yang salah satunya ditopang dengan kehadiran dari integrated criminal justice system. Menurut Barda Nawawi Arief, Sistem Peradilan Pidana pada hakekatnya identik dengan sistem penegakan hukum pidana dan juga diidentikkan dengan sistem kekuasaan kehakiman dibidang hukum pidana yang diwujudkan dalam empat sub sistem, yaitu:65

1. Kekuasaan penyelidik dan penyidikan oleh lembaga penyidik;

2. Kekuasaan penuntutan oleh lembaga penuntut;

3. Kekuasaan mengadili/menjatuhkan putusan oleh badan peradilan, dan;

4. Kekuasaan pelaksanaan hukum pidana oleh aparat pelaksana eksekusi.

Keempat tahap/sub sistem itu merupakan satu kesatuan sistem penegak hukum pidana yang integral, dan sering disebut dengan istilah Sistem Peradilan Pidana Terpadu (integrated criminal justice system). Pemahaman terhadap sistem peradilan pidana terpadu atau SPPT yang sesungguhnya, bukan saja pemahaman dalam konsep "integrasi” itu sendiri, tetapi sistem peradilan pidana yang terpadu juga mencakup makna substansial dari urgensitas simbolis prosedur yang terintegrasi tetapi juga menyentuh aspek filosofis mengenai makna keadilan dan kemanfaatan secara terintegrasi. Sehingga dengan demikian penegakan hukum yang dikawal dan dibingkai oleh norma peraturan perundangan yang menjadi wilayah hukum prosedural, dapat lebih didekatkan pada prinsip dan substansi penegakan hukum yang sekaligus menegakkan keadilan dan penegakan hukum yang bermartabat. 66

\footnotetext{
Andi Hamzah, Hukum Acara Pidana Indonesia, Sinar Grafika, Jakarta, 2013, hlm., 7.

Id, hlm., 31.

66 Id, hlm., 31.
} 
Penegakan hukum terhadap pelanggatan HAM berat yang dilakukan melalui lintas kekuasaan, semakin menjauhkan penegakan pelanggaran HAM berat dari integrated criminal justice system. Integrated criminal justice system adalah upaya integrasi antara penegak hukum secara fungsional dalam proses penyelesaian perkara. Integrated criminal justice system adalah sinkronisasi atau keserempakan dan keselarasan, yang dapat dibedakan dalam: Pertama, sinkronisasi struktural (structural sincronization) yaitu keserempakan dan keselarasan dalam rangka hubungan antar lembaga penegak hukum. Kedua, sinkronisasi substansial (substansial sincronization), yaitu keserempakan dan keselarasan yang bersifat vertikal dan horizontal, dalam kaitannya dengan hukum positif. Ketiga, sinkronisasi kultural (cultural sincronization) yaitu keserampakan dan keselarasan dalam menghayati pandangan-pandangan, sikap-sikap dan falsafat yang secara menyeluruh mendasari jalannya sistem peradilan pidana. ${ }^{67}$ Sasaran yang ingin dicapai dalam sistem ini, agar tahap-tahap proses dari suatu sistem hukum acara pidana menjadi lancar, karena hakikat integrasi tidak lain adalah untuk mengenyampingkan ego sektoral yang selama ini menjadi faktor tersendatnya perkara, khususnya di berkas perkara hasil penyelidikan/ penyidikan ke Penuntutan. 68

Dalam catatan Marwan Effendy, seorang praktisi hukum (Jaksa), harapan terlaksananya sistem peradilan pidana, dengan menggunakan pendekatan sistem melalui administrasi peradilan pidana, sering ternodai oleh berbagai faktor antara lain, faktor ego sektoral, penyalahgunaan wewenangan, difrensiasi SDM yang berkaitan dengan pengetahuan tekhnis yuridis dan manajemen perkara, demoralisasi dari para penegak hukum yang berorientasi pada kebutuhan finansial sehingga menghalalkan segala cara, adanya ketidakpercayaan timbali balik di antara penegak hukum itu sendiri atau saling mencurigai, overlaping kewenangan. Kondisi tersebut mengakibakan sering terjadinya miskomunikasi, misinformasi, diskoordinasi, dan disharmonisasi yang menimbulkan kontra-

67 Marwan Effendy, Teori Hukum dari Prespektif Kebijakan, Perbandingan, dan Harmonisasi Hukum Pidana, Gaung Persada Press Group, Jakarta, 2014, hlm., 394.

68 Id, hlm., 395. 
produktif terhadap proses hukum yang sedang berjalan. ${ }^{69}$ Aspek teoritis dari integrated criminal justice system inilah yang menjadi dasar, diperlukannya penegakan pelanggaran HAM berat yang dilaksanakan secara integral dan terpadu. Sehingga, diperlukannya penataan ulang kelembagaan dan kewenangan di bidang penegakan pelanggaran HAM berat yang berada adalah satu koridor kekuasaan dalam aspek penyelidikan, penyidikan dan penuntutan, sehingga visi dari penegakan pelanggaran HAM berat tercapai. Atas beberapa hal tersebut, penulis merekomendasikan beberapa hal.

Pertama, independensi Komnas-HAM harus ditegaskan secara utuh. Tidak hanya dalam urusan lembaga, dalam sistem penegakan hukum dan kewenangannya-pun harus memiliki independensi yang utuh. Dalam koridor peneguhan independensi Komnas-HAM. Sebagai komisi independen yang mengemban tugas dan fungsi besar dan memakan waktu yang lama, perlu untuk diterapkan model pemilihan komisioner/anggota Komnas-HAM dengan pola staggred terms. ${ }^{70}$ Staggred terms adalah model pergantian pimpinan komisi independen yang dilakukan secara bergilir, semisal jika dalam satu dipimpin oleh 5 orang pimpinan, maka pergantian tidak dilakukan secara bersama-sama, melainkan secara periodik. Pada periode pertama pergantian dilakukan hanya untuk 2 pimpinan, dan sisanya dilakukan dalam periode selanjutnya. Tujuan dari model ini, agar program kerja yang dilaksanakan oleh satu komisi tetap terkonsolidasi, satu frame, dan tidak memulai kembali dari "nol" lantaran pimpinan-nya berganti secara bersama-sama. Masih ada pimpinan lama yang mengetahui dan menjadi komando arah gerak program kerja yang sedang dilaksanakan. Dalam penelitian disertasinya, tidak ada satupun komisi independen di Indonesia yang menggunakan model staggred terms. Jika KomnasHAM menggunakan model ini, maka akan menjadi pionir sekaligus rujukan dalam model pemilihan pimpinan di komisi-komisi independent lainnya.

Kedua, dalam rangka meneguhkan independensi Komnas-Ham dan optimalisasi penegakan pelanggaran HAM berat, perlu untuk memindahkan

\footnotetext{
69 Id, hlm., 397.

70 Zainal Arifin Mochtar, supra. 50, hlm., 61
} 
kewenangan penyidikan dan penuntutan dari Jaksa Agung, kepada Komnas-HAM. Dengan hal ini, maka akan terselenggara penegakan pelanggaran HAM berat dalam satu lingkup kekuasaan, yakni Komnas HAM (sebagai komisi independent). Hal ini perlu dilakukan, juga dalam rangka mewujudkan integrated criminal justice system. Sehingga tidak akan ada lagi silang pendapat/perbedaan visi antara kedua instansi dalam satu perkara tertentu. Jika dilihat dari latar historis dari setiap komisi independen, sejatinya komisi independent selalu mencari "superman and superwoman" untuk menuntaskan permasalahan yang tidak bisa diselesaikan. Dengan peralihan kewenangan penyidikan dan penuntutan kepada Komnas-HAM, maka komisi ini dikomando oleh hukum secara mandiri, dan tidak lagi terkooptasi serta tersubordinasi secara politik dari kekuasaan negara manapun.

Ketiga, selain mengambil alih kewenangan, perlu dilakukan juga berkaitan dengan rekruitmen Jaksa Penuntut Umum Mandiri. Jaksa yang kemudian bertugas di Komnas-HAM, diambil dari Kejaksaan-RI, dan ketika bertugas di Komnas-HAM, maka Jaksa tersebut diberhentikan sementara dari Kejaksaan-RI. Hal ini kuranglebih replika dari penegakan tindak pidana korupsi yang dilakukan oleh KPK. ${ }^{71}$ Muncul pertanyaan besar, bagaimana pengawasan terhadap penegakan pelanggaran HAM berat jika pra-adjudication dilakukan seutuhnya oleh KomnasHAM? Pengawasan itu tentunya dilakukan oleh Pengadilan HAM, sebagai otoritas tunggal yang memutus apakah benar terbukti ada/tidak pelaku dan pelanggaran HAM berat. Hasil kerja terhadap apa yang dilakukan Komnas-HAM tentu akan dinilai di pengadilan, di lain sisi, bagi terdakwa juga memiliki hak untuk membela diri sebagaimana yang dijamin dalam KUHAP.

Strategi seperti inilah yang perlu untuk diterapkan dalam rangka menyelesaikan persoalan pelanggaran HAM berat. Terdapat dua cara yang bisa dilakukan untuk mengeksekusi masalah normatif mengenai Komnas-HAM saat ini, pertama, melalui jalur revisi undang-undang (legislative review). Kedua, melalui

71 Pasal 39 ayat (3) UU KPK: Penyelidik, penyidik, dan penuntut umum yang menjadi pegawai pada Komisi Pemberantasan Korupsi, diberhentikan sementara dari instansi kepolisian dan kejaksaan selama menjadi pegawai pada Komisi Pemberantasan Korupsi. Meskipun terjadi perubahan terhadap UU KPK, melalui Undang-Undang Nomor 19 Tahun 2019 tentang Perubahan Kedua Undang-Undang Nomor 30 Tahun 2002 tentang Komisi Pemberantasan Korupsi, keberadaan pasal ini tidak dilakukan perubahan/revisi. 
penetapan Peraturan Pemerintah Mengganti Undang-Undang (Perppu). Kedua cara ini tentu dapat dilaksanakan dengan satu kunci, yakni political will.

Penataan ulang tersebut, baik secara kelembagaan dan sistem juga merupakan usaha dalam mencapai tujuan dibentuknya lembaga negara atau alat kelengkapan negara. Marwan Mas menegaskan, bahwa tujuan dibentuknya lembaga negara atau alat kelengkapan negara, adalah menjalankan fungsi negara dan fungsi pemerintahan secara faktual. Secara praktis, fungsi lembaga negara dimaksudkan untuk melaksanakan dasar atau ideoligi negara dalam mencapai tujuan negara. Dalam negara hukum yang demokratis, hubungan antara infrastruktur politik (socio political sphere), dimana rakyat selaku pemilik kedaulatan (political sovereignty) dengan suprastruktur politik (governmental political sphere) sebagai pemegan pelaksana kedaulatan rakyat menurut hukum (legal sovereignty), terdapat hubungan yang saling menetukan dan saling mempengaruhi. ${ }^{72}$

Jika pembentuk undang-undang dapat segera menyadari, bahwa pelanggaran HAM berat sebenarnya sederajat dengan tindak pidana korupsi, dan berbagai extra ordinary crime lainnya, dalam batas penalaran yang wajar, maka penyumbatan terhadap penegakan pelanggaran HAM berat akan mendapatkan perhatian penuh, dan intensitas kepedulian yang tinggi. Terlebih, pelanggaran HAM berat adalah jenis perbuatan yang kerugiannya langsung dirasakan oleh rakyat (korban), sehingga jalan apapun harus dapat dilakukan sesegera mungkin: Justice delayed justice denied.

\section{Penutup}

Berdasarkan pembahasan di atas, dapat disimpulkan sebagai berikut, pertama, terhadap penegakan pelanggaran HAM berat, terjadi bolak-balik berkas antara dua institusi, yaitu Komnas-HAM dan Jaksa Agung. Bolak balik berkas itu, diakibatkan oleh penilaian Jaksa Agung yang menganggap berkas penyelidikan tidak memiliki dukungan alat bukti yang kuat. Hal itu mengakibatkan terjadinya pengendapan perkara pelanggaran HAM berat bertahun-tahun dan tidak kunjung

72 Marwan Mas, Hukum dan Konstitusi Kelembagaan Negara, Rajawali Pres, Depok, hlm., 196. 
diadili. Lebih lanjut, terdapat dugaan tidak adanya kesatuan visi penegakan pelanggaran HAM berat antara kedua institusi yakni Jaksa Agung dan Komnas HAM, yang merupakan institusi yang berasal dari dua jenis kekuasaan yang berbeda (Jaksa Agung dari kekuasaan eksekutif, dan Komnas HAM dari Kekuasaan Independent/state auxuliary body.

Kedua, terdapat dua masalah, terjadi permasalahan adanya bolak-balik berkas, yakni masalah kelembagaan dan masalah sistem hukum acara. Salah satu latar belakang komisi independen adalah adanya upaya yang tidak efektif dilakukan oleh salah satu organ kekuasaan (eksekutif). Pelanggaran HAM berat sebagai kejahatan yang memiliki dimensi politik-kekuasaan, tentu harus ditunjang dengan lembaga dan sistem hukum yang memiliki independensi kuat. Atas hal tersebut, perlu kiranya meningkatkan independensi Komnas-HAM, yakni dengan mengambil alih kewenangan penyidikan dan penuntutan dari Jaksa Agung ke Komnas-HAM.

Berdasarkan apa yang telah diuraikan penulis, maka penulis juga menyampaikan beberapa saran, meliputi, menggunakan model pemilihan komisioner/anggota Komnas-Ham dengan pola staggred terms agar program kerja yang dilaksanakan oleh satu komisi tetap terkonsolidasi. Menyerahkan kewenangan penyidikan dan penuntutan dari Jaksa Agung ke Komnas HAM secara langsung demi mewujudkan integrated criminal justice system, dan memberikan kewenangan bagi Komnas-HAM agar dapat melakukan rekruitmen Jaksa Penuntut Umum Mandiri yang yang diambil dari Kejaksaan-RI dan ketika bertugas di Komnas-HAM maka Jaksa tersebut diberhentikan sementara dari Kejaksaan-RI. 


\section{Daftar Pustaka}

\section{Buku:}

Adnan Buyung Nasution, Demokrasi konstitusional: Pikiran \& Gagasan, Penerbit Buku Kompas, Jakarta, 2010

A.V. Dicey, An Introduction to The Study of The Law of The Constitution, Mc Millan, London, 1968.

Andrey Sujatmiko, Hukum HAM dan Hukum Humaniter, PT. Rajagrafindo Persada, Jakarta, 2015.

Bagir Manan dan Susi Dwi Harijanti, Memahami Konstitusi: Makna dan Aktualisasi, PT Raja Grafindo Persada, Jakarta, 2015.

Bambang Waluyo, Penegakan Hukum di Indonesia, Sinar Grafika, Jakarta, 2016.

Eddy O.S. Hiariej, Pengantar Hukum Pidana Internasional, Erlangga, Jakarta, 2009. , Pengadilan atas Beberapa Kejahatan Serius Terhadap HAM. Penerbit Erlangga, Jakarta, 2010.

Ida Elisabeth Koch, Human Rights as Indivisible Rights-The Protection of Socio Economic Demands Under Ther European Convention on Human Rights, Martinus Nijhoff Publishers, Leiden dan Boston, 2009.

Jimly Ashiddiqie, Konstitusi Bernegara Praksis Kenegaraan Bermartabat dan Demokratis, Setara Press, Malang, 2015.

Levitsky, Steven dan Daniel Ziblat, Bagaimana Demokrasi Mati-Apa yang Diungkapkan Sejarah tentang Masa Depan Kita, PT. Gramedia Pustaka Utama, Jakarta, 2019.

Luhut M.P. Pangaribuan, Hukum Acara Pidana, Surat Resmi Advokat di Pengadilan, Papas Sinar Sinanti, Jakarta, 2013.

M. Solly Lubis, Politik dan Hukum di Era Reformasi, Penerbit Mandar Maju, Bandung, 2000.

M.V. Hoecke, Legal doctrine: Which method(s) for what kind of discipline?, Hart Publishing, Oxford, 2011.

Marwan Effendy, Teori Hukum dari Prespektif Kebijakan, Perbandinghan, dan Harmonisasi Hukum Pidana, Gaung Persada Press Group, Jakarta, 2014.

Marwan Effendy, Kejaksaan Republik Indonesia, Posisi, dan Fungsinya dari Prespektif Hukum, PT Gramedia Pustaka Utama, Jakarta, 2005.

Miriam Budiarjo, Dasar-Dasar Ilmu Politik, Gramedia Pustaka Utama, Jakarta, 1998.

Muladi, eds, Hak Asasi Manusia-Hakikat, Konsep, dan Implikasinya Prespektif Hukum dan Masyarakat, Reflika Aditama, Bandung, 2009.

Priscilla B. Hayner, Unspeakable Truth-Facing The Challenge of Truth Commissions, Routledge, New York dan London, 2002.

Satjipto Rahardjo, Ilmu Hukum, Citra Aditya Bakti, Bandung, 2014.

Negara Hukum yang Membahagiakan Rakyatnya, Genta Publishing, Yogyakarta, 2009.

Pendidikan Hukum sebagai Pendidikan Kemanusiaan: Kaitannya dengan Profesi Hukum dan Pembangunan Hukum Nasional, Genta Publishing, Yogyakarta, 2009. 
Suparman Marzuki, Tragedi Politik Hukum dan HAM, Pustaka Pelajar, Yogyakarta, 2011.

Zainal Arifin Mochtar, Lembaga Negara Independen-Dinamika Perkembangan dan Urgensi Penataannya Kembali Pasca Amandemen Konstitusi, PT. Raja Grafindo Persada, Jakarta, 2016.

\section{Jurnal dan Artikel:}

Armunanto Hutahaean, Erlyn Indarti, Lembaga Penyidik Dalam Sistem Peradilan Pidana Terpadu Di Indonesia, Jurnal Legislasi Indonesia Vol 16 No.1 - Maret 2019.

Bagir Manan, Politik Perundang-Undangan Dalam Rangka Mengantisipasi Liberalisasi Ekonomi, Makalah Seminar Nasional tentang Perseroan Terbatas, Bandar Lampung, 1996.

Depri Liber Sonata, Hukum Normatif dan Empiris: Karakteristik Khas Dari Metode Meneliti Hukum, Lex crimen, Volume 8, No. 1, 2017.

Eddy O.S. Hiariej, Asas Legalitas dalam Pelanggaran Hak Asasi Manusia yang Berat, Universitas Gadjah Mada, 2009.

Glendy J. Kaourow, Praperadilan Dalam Perspektif Hak Asasi Manusia Menurut Kitab Undang-Undang Hukum Acara Pidana, Lex crimen Volume 4, No. 8 , 2015.

Haposan Dwi Pamungkas Saragih, Penerapan Putusan Mahkamah Konstitusi Nomor 21/ Puu-Xii/ 2014 Tentang Penetapan Tersangka Sebagai Objek Praperadilan, Lex Et Societas,Volume 4, No. 5, 2016.

Komnas HAM, Jurnal HAM: Komisi Hak Asasi Manusia, Jurnal HAM, Volume 13, No. 8, 2016.

Saldi Isra, Peran Mahkamah Konstitusi dalam Penguatan Hak Asasi Manusia Di Indonesia 1, Jurnal Konstitusi, Volume 11, 2014.

Xavier Nugraha, Maulia Madina, dan Ulfa Septian Dika, Akibat Hukum Berlakunya Putusan MK Nomor 18/PUU/V/2007 Terhadap Usulan DPR Dalam Pembentukan Pengadilan Ham Ad Hoc, Humani, Volume 9, No. 1, 2019.

Zayanti Mandasari, Politik Hukum Pengaturan Masyarakat Hukum Adat (Studi Putusan Mahkamah Konstitus), Jurnal Hukum IUS QUIA IUSTUM, Volume 2, No. 1, 2014.

Zulfadli Barus, Analisis Filosofis Tentang Peta Konseptual Penelitian Hukum Normatif Dan Penelitian Hukum Sosiologi, Jurnal Dinamika Hukum, Volume 13, No. 2, 2014.

\section{Internet:}

Ayomi Amindoni, "Kejaksaan Agung kembalikan berkas kasus pelanggaran HAM berat, bagaimana komitmen Presiden Jokowi?", https://www.bbc.com/indonesia/indonesia-46822119, diakses pada 6 Juni 2019.

Budiarti Utami Putri, "Komnas HAM Sebut Kasus Wasior Wamena Paling Bisa Segera Diproses.”, https://nasional.tempo.co/read/1154059/komnasham-sebut-kasus-wasior-wamena-paling-bisa-segeradiproses/full\&view=ok diakses 6 Juni 2019. 
Devina Halim, "Komnas HAM Kirim Balik 7 Berkas Perkara Pelanggaran Berat HAM ke Kejagung", https://nasional.kompas.com/read/2019/02/20/ 07021381/komnas-ham-kirim-balik-7-berkas-perkara-pelanggaran-beratham-ke-kejagung.

Fabian Januarius Kuwado, "17 Tahun Tragedi Wasior, Kontras Nilai Pemerintahan Jokowi Belum LakukanApa-apa.",https://https://nasional.kompas.com/ $\mathrm{read} / 2018 / 06 / 14 / 10463971 / 17$-tahun-tragedi-wasior-kontras-nilaipemerintahan-jokowi-belum-lakukan-apa

Harian Rakyat Merdeka, "Hasto Atmojo Suroyo: Disiksa, Korban Tragedi Jambu Keupok Berharap Ada Kompensasi Ganti Rugi.", https://www.rmol.co/amp/2016/08/25/258263/Hasto-Atmojo-Suroyo:Disiksa,-Korban-Tragedi-Jambu-Keupok-Berharap-Ada-Kompensasi-GantiRugi-, diakses pada 6 Juni 2019.

Kontras Papua,"Pres Release 12 Tahun peristiwa Wamena 4 April 2003.", http://www.tapol.org/id/news/pres-release-12-tahun-peristiwa-wamena4-april-2003, diakses pada 6 Juni 2019.

Pamflet, "Apa Beda Pelanggaran Ham Dan Tindak Pidana?", https://pamflet.or.id/portfolio/pelanggaran-ham-vs-tindak-pidana-apabedanya/, diakses pada 6 Juni 2019.

\section{Peraturan Perundang-Undangan:}

Undang-Undang Nomor 16 Tahun 2004 Tentang Kejaksaan Republik Indonesia, LN RI Tahun 2004 Nomor 67.

Undang-Undang Nomor 26 tahun 2000 Tentang Pengadilan Hak Asasi Manusia, LN RI Tahun 2000 Nomor 208.

Undang-Undang Nomor 30 Tahun 2002 Tentang Komisi Pemberantasan Tindak Pidana Korupsi, LN RI Tahun 2002 Nomor 137.

Putusan Mahkamah Konstitusi Nomor 65/PUU-II/2004

Putusan Mahkamah Konstitusi Nomor 006/PUU-IV/2006

Putusan Mahkamah Konstitusi Nomor 20/PUU-IV/2006

Putusan Mahkamah Konstitusi Nomor 18/PUU-V/2007

Putusan Mahkamah Konstitusi Nomor 75/PUU-XIII/2015 